\title{
QUALITY CREDIT EVALUATION IN THE INTERNET COMPANY: A SYSTEM BASED ON THE ANALYTIC HIERARCHY PROCESS
}

\author{
Jing YANG ${ }^{1 *}$, Luis G. VARGAS ${ }^{2}$, Xiang JIN ${ }^{3}$, Lijun $\mathrm{ZHOU}^{4}$ \\ ${ }^{1,4}$ College of Economics and Management, China Jiliang University, Hangzhou, China \\ ${ }^{2}$ The Joseph M. Katz Graduate School of Business, University of Pittsburgh, Pittsburgh, USA \\ ${ }^{3}$ School of Slavonic and East European Studies, University College London, London, UK
}

Received 03 October 2018; accepted 11 September 2019

\begin{abstract}
Quality credit has attracted considerable interest in both academia and business world in recent years in China. This study aims to discuss the development of quality credit evaluation system, and then based on an Analytic Hierarchy Process (AHP) to construct an evaluation system for Internet companies. Firstly, the quality credit evaluation three-level pyramid model for Internet companies has been established, including the willingness of quality credit, the ability of quality credit, and the basis of quality credit. Secondly, priorities of the criteria and sub-criteria are assigned and identified by the AHP with 12 experts those who are representatives from Internet companies, research experts, and government staffs. Finally, several US Internet companies are evaluated by using this evaluation system, and practical suggestions are provided for the future based on data evaluation results. This paper finds that in the criteria of quality credit evaluation system, the most significant indicators are credit records and quality of product, while qualification rate of product supervise, operating legitimacy and quality accident are the most primary indicators in the subcriteria level.
\end{abstract}

Keywords: quality credit, analytic hierarchy process, Internet company, evaluation system, quality credit willingness, quality credit ability, quality credit basis.

JEL Classification: L15, L81, C44.

\section{Introduction}

In recent years, product and service quality has increasingly gained relevance in both research and practice. Quality credit plays a considerable role in enhancing the competence of an enterprise and ensuring the satisfaction and trust of consumers, thus increasing profits and growth of the nation's economy. The 43th "China Statistical Report on Internet Development" released by the China Internet Network Information Center (2019) reveals that

\footnotetext{
${ }^{\star}$ Corresponding author. E-mail: yangjing@cjlu.edu.cn
} 
as of December 2018, the scale of China's Internet users reached 829 million, with Internet penetration rate being $59.6 \%$, and the scale of Internet customers reached 610 million. In 2018, the scale of China's e-commerce market transactions was about $\$ 4.65$ trillion. Internet usage in China is growing at a phenomenal rate and has great potential to connect Chinese citizens to its Internet economy and financial marketplace.

The e-commerce market continues to expand, but Chinese Internet enterprises are experiencing an unprecedented crisis in quality. The origin of this problem has been posited to have stemmed from an imbalance between the rapidly growing economy in the past over 30 years and the difficulty of developing standards to keep pace with such an economic boom in China. In 2018, China's Consumer Net received 18868 complaints from customers, and the e-commerce industry accounted for $67.36 \%$ of the total complaints. According to data from China's platform of e-commerce complaints and rights protection public services (2018, www.100ec.cn/zt/315), the main complaints include issues such as refunds (18.46\%), quality of products $(8.25 \%)$, Internet fraud $(7.75 \%)$, false promotions $(5.37 \%)$, consumer services (4.84\%), fraudulent Internet sales $(4.73 \%)$, difficulties returning products $(4.25 \%)$, nonrefundable deposits (3.59\%), and logistics problems (2.57\%), etc.

Undoubtedly, problems in e-business concerning quality credit have become a focal point for researchers studying the growing e-business market at present in China. While many of credit studies exist regarding manufacturing industry or service industry, none as yet have focused on the quality credit system for the Internet companies. This paper will review the background of the quality credit system and propose a new method for implementing a quality credit system for Internet companies.

The purpose of this paper is to construct a quality credit evaluation system for the Internet company, and using it to evaluate some Internet companies' quality credit and propose relevant suggestions for them. In order to achieve the above purpose, the Internet company is used to as the research object, and there are three main research methods in this paper: literature review method, expert interview method and AHP analysis method.

The remainder of this paper is structured as follows. Section 1 presents a quality credit literature review. The process of constructing the quality credit evaluation system is discussed in Section 2. Next, Section 3 describes the evaluation method. Subsequently, the calculating weights of evaluation system is shown in Section 4. Finally, giving the example and drawing the conclusion in Section 5 and last section, respectively.

\section{Quality credit literature review}

The concept of credit has been primarily associated with the finance industry in which it is referred to as credit risk. However, credit and quality are inseparable in China. There exists a distinction between financial credit risk and quality credit. A search in the Chinese database (www.cnki.net) shows that the earliest reference to "quality credit" as a research topic appeared in 2000. In this research, Liu and Yang (2000) believe that the concept of quality credit is the same as the qualification rate and the excellent product rate. Li (2017) also demonstrates that many companies have gradually attached importance to the credit value stand up. As of 2018, 435 essays about "quality credit," 568 essays about "quality honesty," 
and 577 essays about "quality reputation" can be found in that database. Figure 1 provides the statistics of published research concerning quality credit in the Chinese database from 2002 to 2018.

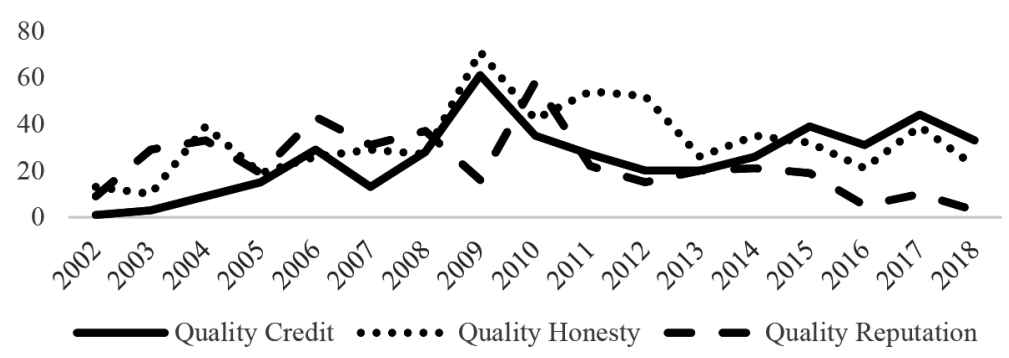

Figure 1. Number of quality credit essays in Chinese database

With the strong company credit, the Internet company will have the opportunity to acquire credit qualification and more available financing channels (Sheng, 2008). Meanwhile, due to strict regulation measures of the bond issuance in China which means companies cannot issue bonds unless they obtain $3 \mathrm{~A}$ credit rating, companies are more likely to windowdress the operating results to obtain a higher credit rating (Guo, 2017). Zhou and Tu (2018) illustrate that quality credit is one of the company's important assets. It can directly and indirectly affect the performance of the company, and also is a powerful tool to enhance the stable development and competition of this company.

\subsection{Definition of quality credit}

In contrast to financial credit risk, quality credit has different definitions and meanings for various industries (Barrett, 2009). Considerable differences exist among manufacturing, services, and Internet businesses. Thus, when studying quality credit, scholars limit their research to a specific industry (Agus \& Sagir, 2001; Amar \& Zain, 2002; Jabnoun \& Sedrani, 2005; Ye et al., 2010; Zhang \& Gao, 2010). In this paper, the research area is limited in Internet companies, especially business-to-business (B2B) or business-to-customer (B2C).

Quality credit was first proposed by the General Administration of Quality Supervision, Inspection and Quarantine (GAQSIQ) of the People's Republic of China. In 2009, the GAQSIQ and the Standardization Administration of the People's Republic of China (SAC) jointly released the recommended national standard in which quality credit is defined as "A Company's ability and extent to which it (1) complies with the quality laws and regulations, (2) implements standards, and (3) fulfills the quality commitment in production and operation activities". At present, most scholars from America and Europe regard that the quality credit is a part of company credits, and as the primary evaluation item of "company capacity," "company character" and "company capital" which constitute the essential elements of the 3C evaluation model.

Scholars have not achieved consensus on the definition of quality credit yet. Table 1 provides a wide range of interpretations of quality credit from studies over the last ten years. 
Table 1. Definition of quality credit

\begin{tabular}{|l|l|}
\hline \multicolumn{1}{|c|}{ Authors } & \multicolumn{1}{c|}{ Definition } \\
\hline $\begin{array}{l}\text { General Administration of Quality } \\
\text { Supervision, Inspection and } \\
\text { Quarantine (GAQSIQ) of the People's } \\
\text { Republic of China (2006); Zhu et al. } \\
\text { (2012) }\end{array}$ & $\begin{array}{l}\text { An enterprise's capacity and performance in complying } \\
\text { with laws as well as its commitment to its product quality }\end{array}$ \\
\hline $\begin{array}{l}\text { General rules of grading enterprise } \\
\text { quality credit (GB/T23791-2009); } \\
\text { Liu et al. (2011) }\end{array}$ & $\begin{array}{l}\text { The ability and extent of compliance with quality laws } \\
\text { and regulations, implementation standards, and quality } \\
\text { commitments in production and operating activities }\end{array}$ \\
\hline Zhou et al. (2012) & $\begin{array}{l}\text { An enterprise's ability and extent of compliance with } \\
\text { quality laws and regulations, implementation standards, } \\
\text { and quality commitments in production and operating } \\
\text { activities }\end{array}$ \\
\hline Jiang (2004) & $\begin{array}{l}\text { An enterprise quality credit includes performance } \\
\text { commitment and performance capacity }\end{array}$ \\
\hline Xiong et al. (2013) & $\begin{array}{l}\text { An enterprise's ability to make quality commitments to } \\
\text { customers in market trading activities and its extent of } \\
\text { quality commitment }\end{array}$ \\
\hline Xiong and Liu (2009) & $\begin{array}{l}\text { The ability and degree of the company's compliance with } \\
\text { quality laws and regulations, implementation standards } \\
\text { and quality commitments in productions and operations }\end{array}$ \\
\hline
\end{tabular}

Due to different cultural characteristics, the credit environment, and the basis of industry development, the system to evaluate quality credit must consider factors such as the level of economic development, industry characteristics, and specific features of various regions and trades. In this paper, based on the industry credit environment, quality credit is defined as the willingness and ability of a company to meet consumers' demands and expectations when fulfilling its obligations on its products and services while complying with laws and regulations, implementation standards, and quality commitments.

\subsection{Quality credit evaluation}

No consensus exists among researchers working on the development of quality credit evaluation systems. In case study, different industries exist different characteristics, which should be considered in the whole research process. Zhu et al. (2012) focus on the air-conditioning market and consider factors such as an enterprise's potential ability, its willingness to satisfy customer needs, and practical performance, but the research focuses mainly on product quality. Liu et al. (2011) evaluate all industries and propose one quality credit rating which includes three main areas: trustworthiness, the ability to guarantee the quality, and quality credit performance. The specific dimensions of the different evaluation systems are summarized in Table 2. 
Table 2. Dimensions of quality credit considered in the literature

\begin{tabular}{|c|c|c|}
\hline Authors & Dimension & Industry \\
\hline Zhu et al. (2012) & $\begin{array}{l}\text { Enterprise's potential ability; Enterprise's willingness; } \\
\text { Practical performance }\end{array}$ & $\begin{array}{l}\text { Air-conditioning } \\
\text { market }\end{array}$ \\
\hline Liu et al (2011) & $\begin{array}{l}\text { Enterprise trustworthy will; Enterprise's ability } \\
\text { of guaranteeing quality; Enterprise quality credit } \\
\text { performance }\end{array}$ & All industry \\
\hline $\begin{array}{l}\text { Zhang and Gao } \\
(2010)\end{array}$ & $\begin{array}{l}\text { Quality strategies; Quality resources; Process control; } \\
\text { Quality economy; Customer satisfaction }\end{array}$ & $\begin{array}{l}\text { Household Appliance } \\
\text { Industry }\end{array}$ \\
\hline $\begin{array}{l}\text { General rules of } \\
\text { grading enterprise } \\
\text { quality credit (GB/ } \\
\text { T23791-2009) }\end{array}$ & $\begin{array}{l}\text { Organization construction; Trustworthiness } \\
\text { construction; Product quality; Social responsibility; } \\
\text { Quality records; Social supervision }\end{array}$ & All industry \\
\hline Jiang (2004) & $\begin{array}{l}\text { The willingness of quality credit; The ability of quality } \\
\text { credit }\end{array}$ & All industry \\
\hline Zhou et al. (2012) & $\begin{array}{l}\text { Enterprise trustworthiness; Enterprise's ability of } \\
\text { providing quality; Enterprise's ability of guaranteeing } \\
\text { quality restraint force }\end{array}$ & All industry \\
\hline Xian and Ye (2008) & $\begin{array}{l}\text { The guaranteeing ability of enterprise and product } \\
\text { credit; Enterprise's ability; Enterprise's quality } \\
\text { performance }\end{array}$ & All industry \\
\hline Xiong et al. (2013) & $\begin{array}{l}\text { The trustworthiness of quality credit; The ability of } \\
\text { quality credit }\end{array}$ & $\begin{array}{l}\text { Manufacturing } \\
\text { Industries in } \\
\text { Zhejiang Province }\end{array}$ \\
\hline $\begin{array}{l}\text { Luo and Tan (2017) } \\
\text { Wang and Mo } \\
\text { (2019) }\end{array}$ & $\begin{array}{l}\text { The willingness of quality credit; The guaranteeing } \\
\text { ability of quality credit; The performance of quality } \\
\text { credit }\end{array}$ & $\begin{array}{l}\text { Manufacturing } \\
\text { Industries; All } \\
\text { industry }\end{array}$ \\
\hline
\end{tabular}

\subsection{Quality credit evaluation of the internet industry}

In this study, quality credit willingness and ability are used in the quality credit evaluation system, which are the most important factors and the most frequently used factors in existing research. In addition, quality credit is based on the industry environment, and the average quality credit of different industries varies greatly because it is closely related to the regulation and policy support of the entire industry. Thus, the industry environment cannot be ignored. Hence, in this study, the environment is added to the developed three-level pyramid model: (1) the basis of quality credit, which means the industry environment, (2) ability to provide quality products or services, and (3) willingness to provide quality products or services.

For Internet companies, the three-level model is further divided into subcategories (Figure 2). Quality credit willingness is divided into credit records and company status; credit records include laws and regulations, consumer perceptions, and default. Regarding quality credit ability, in addition to product quality, according to the features of Internet companies, the evaluation should also include service quality, which plays an important role in improving Internet companies' comprehensive quality and competition. 


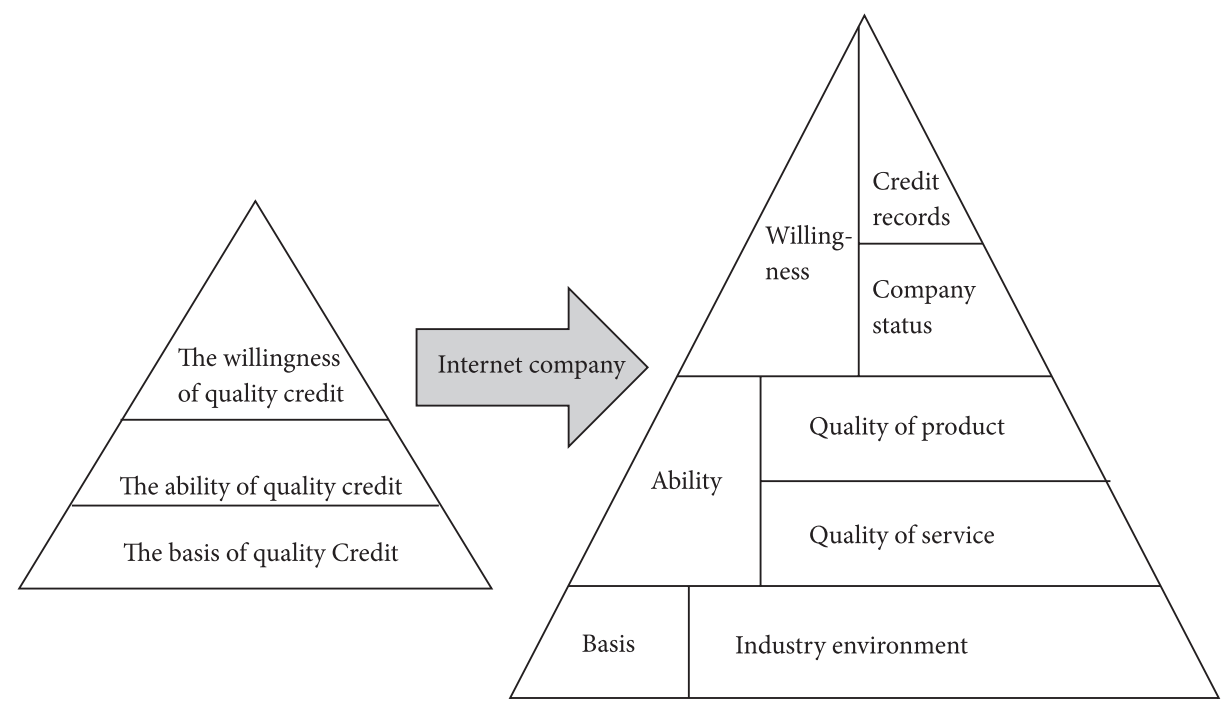

Figure 2. Quality credit evaluation pyramid

\section{Quality credit evaluation system}

\subsection{Quality credit willingness}

For the willingness to maintain quality credit, the company, law, and encouragement layers are adopted (Zhu et al., 2012). Zhou et al. (2012) propose that willingness should include the external environment, short-term and long-term goals, legal qualification, and production license. In the research of Liu et al. (2011), company trustworthy willingness includes brand building and honors. In this study, quality credit is subdivided into two parts: credit record and company status (Figure 3). Credit records mainly include three levels: the first one is related to illegal and default records, the second is related to consumer records, such as false advertising and consumer complaints, and the third contains quality default and quality accidents. Company status mainly includes the legal operation of the company, the position of the company in the industry, and the honors obtained by the company.

\subsection{Quality credit ability}

Quality credit ability refers to the potential ability to execute a company's commitment to quality. Most studies consider the ability of a company to develop quality products. The usual criteria involved include research investment, quality investment, technical ability, quality certification, adopted standards, and profitability (e.g., Zhu et al., 2012; Liu et al., 2011).

This study focuses on Internet companies which are widely diverse and quite different from manufacturing companies. Therefore, the characteristics of Internet companies also include the evaluation of the ability to deliver service quality. Service ability consists of four levels: service personnel, service process, payment security, and logistics ability. The evaluation of service staff also includes their attitudes and abilities. The process consists of response time, problem-solving, and after-sales service. Figure 4 summarizes these criteria. 


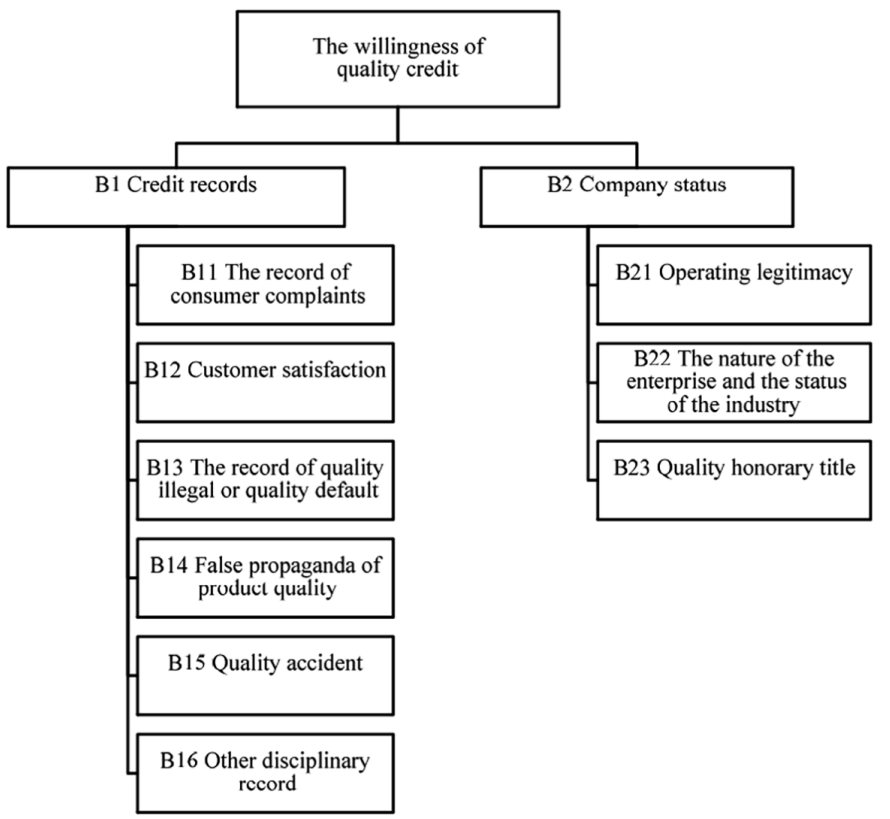

Figure 3. Hierarchy of quality credit willingness

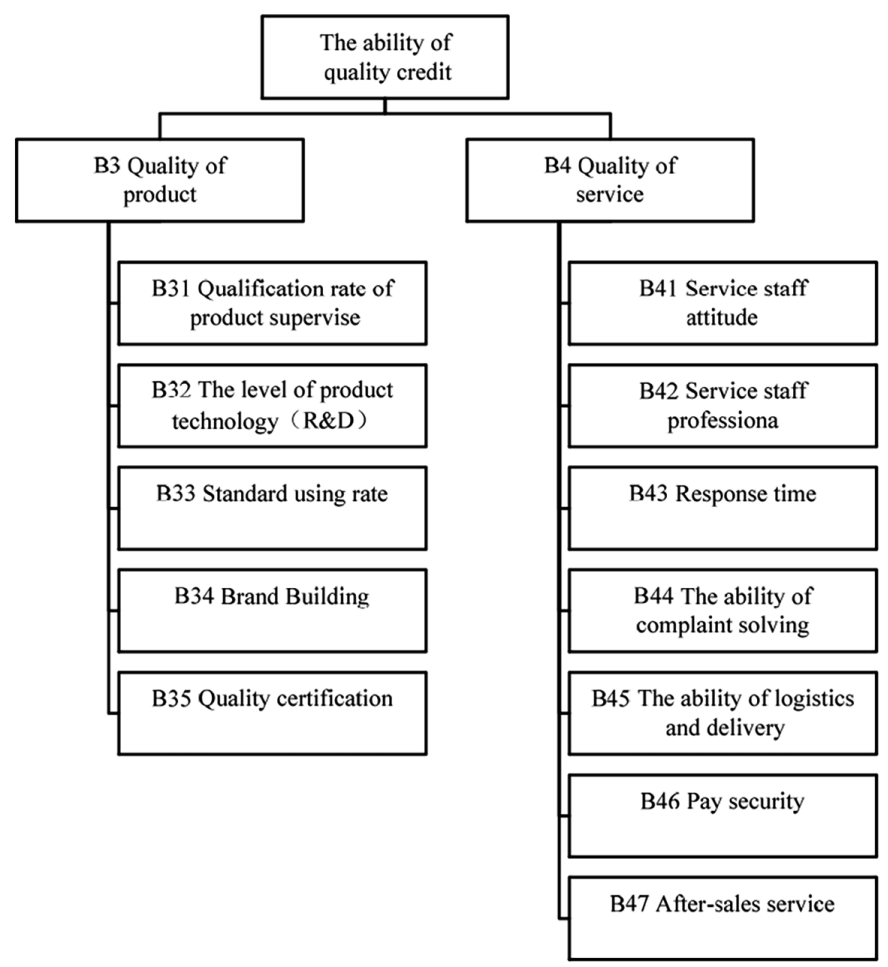

Figure 4 . Hierarchy of quality credit ability 


\subsection{Quality credit basis}

Quality credit is based on the industry environment. Different industries differ considerably in terms of average quality credit, which is closely related to the supervision level and policy support of the industry. Therefore, the industry credit environment cannot be ignored. Moreover, studies refer to the credit environment only as a willingness or performance indicator (e.g., Zhu et al., 2012; Liu et al., 2011; Zhou et al., 2012). In this study, the basis of quality credit is assumed to be independent of industry regulation, industry development, industry penalties, and industry-related laws and regulations that are used to evaluate its completeness (Figure 5).

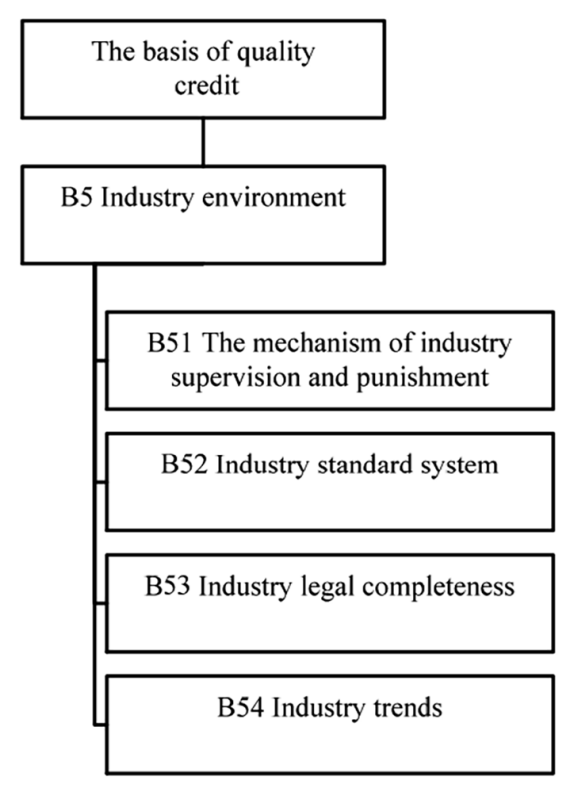

Figure 5. Hierarchy of quality credit basis

\section{Evaluation method}

\subsection{Basics of the Analytic Hierarchy Process}

The Analytic Hierarchy Process (AHP) is a structures and hierarchical decision-making method, which was developed in the mid-1970s by Thomas Saaty in order to overcome the cognitive limitations of decision makers (Saaty, 1977). It is one of the most suitable multicriteria approaches for evaluation.

AHP is simple and easy to use and enables users to represent knowledge in the form of hierarchies that combine different types of tangible and intangible criteria. The underlying mechanism of the AHP is pairwise comparisons. Giving a criterion at a certain hierarchical level, the elements at the level below are connected to this criterion and are compared in pairs with respect to this criterion in order to determine which element is more important and by how much. The absolute scale used to answer these questions is presented in Table 3. 
Table 3. Judgment absolute scale (source: Yurdakul \& Iç, 2004)

\begin{tabular}{|l|c|}
\hline \multicolumn{1}{|c|}{ Verbal judgment of preference } & Numerical rate \\
\hline Equal importance & 1 \\
\hline Moderate importance & 3 \\
\hline Strong importance & 5 \\
\hline Demonstrated importance & 7 \\
\hline Absolute importance & 9 \\
\hline Intermediate values between the two adjacent judgments & $2,4,6,8$ \\
\hline $\begin{array}{l}\text { If activity i has one of the above numbers assigned to it when compared } \\
\text { with activity j; then } j \text { has the reciprocal value when compared with i }\end{array}$ & $\begin{array}{c}\text { Reciprocal of above } \\
\text { numbers }\end{array}$ \\
\hline
\end{tabular}

To compare the criteria in the quality credit hierarchy, the data was gathered from 12 experts via questionnaire and in-person interviews in Zhejiang, China from June 2016 to August 2016. In the interviews, $1 / 3$ of the interviewees were management-level professionals or CEOs of Internet companies, $1 / 3$ were university professors, and 1/3 were government officials who specialized in quality management.

In each matrix, the number in row $i$ and column $j$ provides the relative importance of a certain criterion over another criterion. The matrix form is given by Eq. (1):

$$
A=\left[a_{i j}\right]=\left[\begin{array}{ccccc}
1 & a_{12} & a_{13} & \ldots & a_{1 j} \\
1 / a_{12} & 1 & a_{23} & \ldots & a_{1 j} \\
1 / a_{12} & 1 / a_{12} & 1 & \ldots & a_{1 j} \\
\ldots & \ldots & \ldots & 1 & \ldots \\
1 / a_{12} & 1 / a_{12} & 1 / a_{12} & \ldots & 1
\end{array}\right] .
$$

Then, the judgments obtained from the experts are combined using the geometric mean (Aczel \& Saaty, 1983). The geometric mean aggregation procedure of the judgments of individuals in a group satisfies Arrow's conditions (Saaty \& Vargas, 2012). It is given by Eq. (2):

$$
f(P)\left(A_{i}, A_{j}\right)=\left[\prod_{k=1}^{n} P_{k}\left(A_{i}, A_{j}\right)\right]^{1 / n},
$$

where $P_{k}\left(A_{i}, A_{j}\right)$ represents the pairwise comparison of elements $\left(A_{i}, A_{j}\right)$ with respect to a criterion by the $k^{\text {th }}$ expert. In this case, $n=12$.

Let $A$ denote the matrix of pairwise comparisons. Note that this matrix is reciprocal. That is, $P_{k}\left(A_{j}, A_{i}\right)=1 / P_{k}\left(A_{i}, A_{j}\right)$, for all $i$ and $j$. Weights are extracted from the matrix of pairwise comparisons through the eigenvector method.

The next step of the process is to calculate the weight vector for each criterion. The method involves finding a vector $\hat{\mathrm{x}}$ such that it satisfies

$$
A \hat{x}=\lambda_{\max } \hat{x}
$$

where $\lambda_{\max }$ is the eigenvalue with the largest modulus, known as the principal eigenvalue of $A$ (Saaty, 1977; Saaty \& Vargas, 2012). 
The last step is to test the consistency, which is proposed by Saaty (1977). In the application of the AHP, the consistency of judgments must be assessed by calculating the consistency ratio (CR),

$$
C R=\frac{C I}{R I}
$$

where $C I=\frac{\lambda_{\max }-n}{n-1}$ and RI is a quantile of the distribution of CI obtained from a randomly generated matrix of order $n$. In general, the CR value should be less than $10 \%$ if judgments are to be considered consistent (Saaty, 1977). Otherwise, the more inconsistent judgments should be revised. Inconsistency maybe due to lack of information or lack of knowledge, and the problem may need to be more accurately structured (Cheng \& Li, 2001; Yurdakula \& Iç, 2004).

\subsection{Strengths and weaknesses of the AHP}

The AHP has strengths and weaknesses as the same as other methods, but an extensive discussion on its advantages and shortcomings is beyond the scope of this study. The AHP has been characterized as simple, solidly supported on mathematical background and able to assess quantitative and qualitative factors (Ferreira et al., 2014). One of the most significant strengths of the AHP is easy to use, which only requires individuals to make comparisons only between pairs of alternatives (Saaty, 2008; Ferreira et al., 2014). Moreover, the judgment matrix under AHP is easier to construct, and the calculation of the value is convenient.

On the other hand, the AHP also has caused different types of criticism, including the possibility of exhibiting rank reversal (Belton \& Gear, 1983), and consistency measures (Alonso \& Lamata, 2006). It is important to underline, in recent years, many important advances have been made. Saaty and Vargas (2007) develop the geometric dispersion as a measure of the consistency and homogeneity of the group. If there are interdependencies between factors in the hierarchy, the AHP will no longer work, and The Analytic Network Process (ANP) would be replaced. ANP is developed on the basis of AHP, which has the same steps, ranking methods, and scale selection methods as the AHP.

In the evaluation of credit, the AHP is one of the most used method. By using AHP Approach, Mustafa \& Yusuf (2004) classify the credit evaluation, the relevant criteria, subcriteria and measures, and use them in the hierarchical decision structure to calculate overall credibility scores for applicant manufacturing firms. Zeliha and Girginer (2015) applies AHP to determine the weight of the criteria named bank's commercial credit applications evaluation. Yu et al. (2019) employed AHP and fuzzy comprehensive evaluation methods to calculate the personal credit scores. Ferreira and Santos (2016) analysed the credit risk of mortgage loans, and considered that AHP is the overall excellent approach. Therefore, the AHP-based quality credit evaluation system is also suitable and solidly supported on literature in this study.

\subsection{The analysis of consistency and homogeneity of the group}

In AHP, groups make decisions by building a hierarchy and providing judgments. To use the geometric mean of individual judgments as the representative judgment for the entire group, 
the dispersion of a group must be statistically acceptable. Because the judgments satisfy the reciprocal property, the variance of the judgments cannot be obtained in the traditional statistical fashion (i.e., as the average of the squared deviations from the mean). Saaty and Vargas (2007) develop the geometric dispersion as a measure of the variation of reciprocal judgments.

Let $\left\{x_{1}, x_{2}, \ldots, x_{n}\right\}$ be the judgments of $\mathrm{n}$ experts about one pairwise comparison. Let $\left\{x_{[1: n]}, x_{[2: n]}, \ldots, x_{[n: n]}\right\}$ be the ordered values, where $x_{[k: n]} \leq x_{[k+1: n]}$. Let $\bar{x}_{G}$ be the geometric mean of the judgments. The sample geometric dispersion of the judgments of a group $\left\{x_{1}, x_{2}, \ldots, x_{n}\right\}$ is given by

$$
s_{G}\left(x_{1}, x_{2}, \ldots, x_{n}\right)=\left[\frac{\prod_{k=1}^{n}\left(x_{[k: n]}\right)^{1 / n}}{\prod_{h=1}^{n_{1}}\left(x_{[h: n]}\right)^{1 / n_{1}}}\right]^{2 n_{1} / n},
$$

where $n_{1}$ is the index value for which $x_{[h: n]} \leq \bar{x}_{G}$ for $h=1,2, \ldots, n_{1}$.

As the number of decision-makers increases, the sample geometric variance converges to a three-parameter gamma distribution:

$$
\operatorname{Gamma}(\alpha, \beta, \gamma)=\frac{\beta^{\alpha}}{\Gamma(\alpha)}(x-\gamma)^{\alpha-1} e^{-\beta(x-\gamma)} .
$$

The gamma distribution parameters, with a location parameter equal to 1 (Table 4 ), are estimated through simulation for a sample size of 100,000 (Saaty \& Vargas, 2007).

In this study, 12 experts were invited to do the survey. Figure 6 gives the gamma distribution for $n=12$.

Table 4. Gamma distribution parameters () of the sample geometric dispersion

\begin{tabular}{|c|c|c|c|c|c|}
\hline$n$ & Shape $\alpha$ & Scale $\beta$ & $n$ & Shape $\alpha$ & Scale $\beta$ \\
\hline 8 & 7.67909 & 3.1141 & 13 & 14.4586 & 5.55345 \\
\hline 9 & 9.29459 & 3.68852 & 14 & 16.0157 & 6.10734 \\
\hline 10 & 10.4217 & 4.08574 & 15 & 17.4963 & 6.65405 \\
\hline 11 & 11.8255 & 4.59905 & 20 & 24.2381 & 9.02191 \\
\hline 12 & 13.0628 & 5.04772 & 30 & 38.5573 & 14.1547 \\
\hline
\end{tabular}

Gamma (3-Parameter) distribution

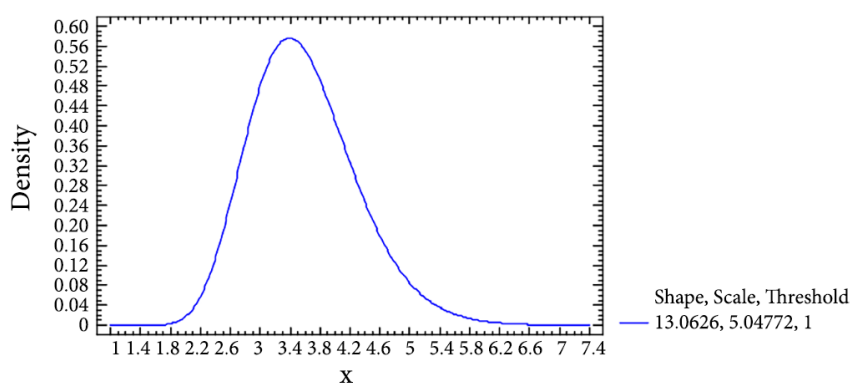

Figure 6. Sample geometric dispersion distribution $(\mathrm{n}=12)$ 
Based on the above information, the next section is to test whether the probability of obtaining the value of the observed sample geometric dispersion of the group is greater than a pre-specified significance level (e.g., 1\%). If the p-value is small (e.g., less than 0.01), then these indicate that it seems rare to observe values of the geometric dispersion smaller than the sample geometric dispersion; the geometric mean can be used as the representative preference judgment for the entire group.

\section{Weights of evaluation system}

\subsection{Weights for quality credit willingness}

(1) Credit records

First, the experts should evaluate items under credit records. The geometric mean method is used to synthesize the experts' judgments (Table 5).

As indicated by the geometric dispersion of the judgments of the expert group for each pairwise comparison (Table 5, row 15) and their corresponding p-values (Table 5, row 16), most of judgments have a small geometric dispersion () except for judgments highlighted in Table 5. Only two of these judgments have a p-value greater than 0.05 . These results signify that geometric mean may be used as the representative judgment for the group. Although, if one has doubts about how often rank reversal could take place because of the geometric dispersion is not small enough, one could perform a simulation using the matrix given below where the highlighted entries 0.6753 and 0.5265 in the matrix below are substituted with the intervals $[1 / 5,5]$ and $[1 / 7,3]$, respectively. The simulation would assume a reciprocal uniform distribution in those intervals. The simulation result would show the priority intervals and the probability of rank reversal for the items being compared (MorenoJimenez \& Vargas, 1993).

Secondly, the pairwise judgment matrix is presented as follows:

$$
d_{x}=\left[\begin{array}{llllll}
1 & 2.0370 & 0.3164 & 0.5078 & 0.2517 & 0.9369 \\
0.4909 & 1 & 0.2782 & 0.6753 & 0.2435 & 0.5265 \\
3.1602 & 3.5944 & 1 & 2.7860 & 0.5637 & 2.2038 \\
1.9693 & 1.4807 & 0.3589 & 1 & 0.2856 & 1.2009 \\
3.9737 & 4.1075 & 1.7741 & 3.5020 & 1 & 3.9468 \\
1.0674 & 1.8994 & 0.4538 & 0.8327 & 0.2534 & 1
\end{array}\right] .
$$

Finally, the weights (or priorities) of the sub-criteria included in credit records along with the consistency index are obtained as follows:

$$
W_{b 1}=\left(\begin{array}{c}
0.0908 \\
0.0662 \\
0.2518 \\
0.1168 \\
0.3710 \\
0.1033
\end{array}\right), \mathrm{CI}=0.02226, \mathrm{CR}=0.01795<0.1 .
$$




\begin{tabular}{|c|c|c|c|c|c|c|c|c|c|c|c|c|c|c|c|}
\hline$\stackrel{\bar{n}}{\infty} \frac{0}{\infty}$ & in & - & in & $\sim$ & $\infty$ & $m$ & $a$ & $m$ & $m$ & $\wedge$ & $m$ & $\wedge$ & $\begin{array}{l}\infty \\
0 \\
o \\
o \\
m \\
m\end{array}$ & 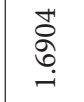 & \& \\
\hline$\stackrel{\nexists}{\vec{\infty}} \stackrel{0}{\infty}$ & $m$ & - & $\stackrel{\sim}{=}$ & $\sim$ & in & -1 & $\stackrel{20}{=}$ & $\stackrel{\sim}{=}$ & - & $m$ & -1 & in & 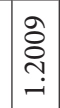 & $\begin{array}{l}\stackrel{n}{0} \\
m \\
\text { in }\end{array}$ & 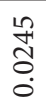 \\
\hline$\underset{\mathscr{D}}{\vec{D}} \frac{n}{\infty}$ & $\stackrel{10}{=}$ & -1 & $\triangleq$ & $\underset{J}{\Xi}$ & $\stackrel{10}{=}$ & $\stackrel{\varrho}{=}$ & $\stackrel{\vartheta}{\beth}$ & $\stackrel{\searrow}{\Xi}$ & $\stackrel{\sim}{=}$ & $\stackrel{\Re}{=}$ & $\stackrel{\varrho}{=}$ & $\stackrel{2}{\approx}$ & $\begin{array}{c}0 \\
L \\
1 \\
0 \\
\sim \\
0\end{array}$ & 突 & $\begin{array}{l}8 \\
8 \\
0\end{array}$ \\
\hline$\stackrel{\bar{m}}{\bar{n}}$ & in & - & $\stackrel{\text { in }}{=}$ & $N$ & $m$ & $m$ & $a$ & $m$ & $m$ & -1 & $m$ & $m$ & $\begin{array}{c}\infty \\
\tilde{N} \\
\tilde{N} \\
\sim \\
\sim\end{array}$ & 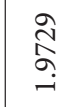 & $\begin{array}{l}0 \\
\stackrel{-1}{8} \\
\stackrel{0}{0}\end{array}$ \\
\hline$\stackrel{\bar{m}}{n} \frac{n}{m}$ & $\stackrel{m}{=}$ & $\rightarrow$ & $\stackrel{\vartheta}{\jmath}$ & $\sim$ & $\stackrel{m}{=}$ & $\stackrel{\curvearrowright}{\Xi}$ & -1 & $\stackrel{\Sigma}{\Xi}$ & $\stackrel{\curvearrowright}{\Xi}$ & - & -1 & $\stackrel{m}{=}$ & $\begin{array}{l}\hat{\tilde{\sigma}} \\
\tilde{L} \\
0\end{array}$ & $\begin{array}{l}\stackrel{\partial}{\circ} \\
\stackrel{\infty}{-}\end{array}$ & $\begin{array}{l}\text { ô } \\
\text { } \\
0 \\
0\end{array}$ \\
\hline$\vec{m} \stackrel{\vec{n}}{\vec{n}}$ & in & - & in & H & $m$ & $m$ & $a$ & $m$ & $m$ & - & - & $m$ & $\begin{array}{c}8 \\
\infty \\
\infty \\
\\
i\end{array}$ & $\underset{-}{\vec{\delta}}$ & ஓ̊ \\
\hline$\underset{\oplus}{\stackrel{\varpi}{\infty}}$ & $\stackrel{\varrho}{=}$ & $\triangleq$ & $\triangleq$ & in & $\stackrel{m}{=}$ & - & $\stackrel{n}{2}$ & -1 & -1 & $\stackrel{2}{=}$ & $m$ & $\stackrel{n}{=}$ & 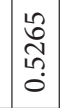 & $\begin{array}{l}\text { ठ } \\
8 \\
0 \\
i \\
i\end{array}$ & $\begin{array}{l}\infty \\
\infty \\
\infty \\
0 \\
0 \\
0\end{array}$ \\
\hline$\underset{\ddot{n}}{\stackrel{\imath}{n}}$ & $\stackrel{10}{=}$ & $\stackrel{2}{=}$ & $\stackrel{20}{=}$ & $\infty$ & $\stackrel{\vartheta}{=}$ & $\stackrel{n}{2}$ & 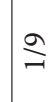 & $\stackrel{n}{2}$ & $\stackrel{m}{=}$ & $\stackrel{n}{2}$ & $\stackrel{\cong}{=}$ & $\stackrel{\partial}{\partial}$ & $\begin{array}{l}\tilde{n} \\
\stackrel{7}{\sim} \\
\tilde{o}\end{array}$ & 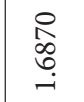 & ஓ̊ \\
\hline$\underset{\oplus}{\stackrel{\varpi}{n}}$ & $m$ & $\stackrel{10}{=}$ & $m$ & in & $\stackrel{n}{=}$ & $\stackrel{\sim}{\beth}$ & $\stackrel{m}{=}$ & $\stackrel{ }{=}$ & $\stackrel{\sim}{\sim}$ & $\stackrel{n}{2}$ & $m$ & $\stackrel{\sim}{\cong}$ & $\begin{array}{l}n \\
\hat{n} \\
6 \\
0 \\
0\end{array}$ & 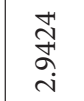 & $\begin{array}{l}0 \\
10 \\
\infty \\
0 \\
0\end{array}$ \\
\hline$\underset{\infty}{\stackrel{m}{n}}$ & $\stackrel{10}{=}$ & $\stackrel{a}{-}$ & $\stackrel{n}{=}$ & $\infty$ & $\triangleq$ & $\stackrel{n}{2}$ & $\stackrel{n}{2}$ & $\stackrel{\cong}{=}$ & $\stackrel{n}{2}$ & $\stackrel{n}{2}$ & $\stackrel{\varrho}{=}$ & $\triangleq$ & 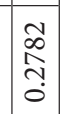 & 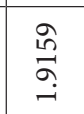 & 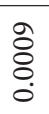 \\
\hline $\begin{array}{l}\exists \\
\vec{m} \\
\vec{\infty}\end{array}$ & $\neg$ & $\stackrel{\curvearrowright}{=}$ & $m$ & $\sim$ & $v$ & $v$ & $\stackrel{\llcorner}{二}$ & -1 & $v$ & $\stackrel{m}{=}$ & $m$ & $\triangleq$ & $\begin{array}{l}\hat{\sigma} \\
\hat{\sigma} \\
\hat{\sigma}\end{array}$ & $\begin{array}{l}\stackrel{n}{\alpha} \\
\stackrel{+}{+} \\
\stackrel{1}{i}\end{array}$ & 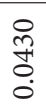 \\
\hline$\exists \frac{n}{m}$ & $\stackrel{10}{=}$ & $\stackrel{a}{-1}$ & 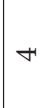 & $\stackrel{\bullet}{=}$ & $\triangleq$ & $\stackrel{m}{=}$ & $\stackrel{2}{=}$ & $\stackrel{\cong}{=}$ & $\stackrel{m}{=}$ & $\stackrel{20}{=}$ & $\stackrel{m}{=}$ & $\stackrel{\vartheta}{\beth}$ & 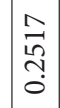 & $\stackrel{\stackrel{n}{\approx}}{\overparen{a}}$ & $\begin{array}{l}\text { Oे } \\
\text { ठ̊. }\end{array}$ \\
\hline$\vec{\nexists} \underset{\infty}{\vec{n}}$ & $\neg$ & $\stackrel{\vartheta}{\lambda}$ & $m$ & - & $\stackrel{m}{=}$ & - & 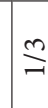 & $\stackrel{N}{=}$ & -1 & $\stackrel{m}{=}$ & $\stackrel{m}{=}$ & $\triangleq$ & $\begin{array}{l}\infty \\
\stackrel{0}{0} \\
1 \\
0 \\
0\end{array}$ & $\underset{\sim}{\stackrel{H}{J}}$ & $\begin{array}{l}\text { fo } \\
\text { Oे } \\
0\end{array}$ \\
\hline$\exists \frac{m}{m}$ & $\stackrel{m}{=}$ & $\triangleq$ & $\stackrel{m}{=}$ & - & $\stackrel{n}{=}$ & $\stackrel{m}{=}$ & $\stackrel{n}{2}$ & $\stackrel{\sim}{\curvearrowright}$ & $\stackrel{m}{=}$ & $\stackrel{n}{2}$ & - & $\triangleq$ & $\begin{array}{l}\vec{b} \\
\tilde{n} \\
0\end{array}$ & $\underset{\hat{\sigma}}{\hat{\sigma}}$ & $\begin{array}{l}8 \\
8 \\
0 \\
0\end{array}$ \\
\hline $\overrightarrow{\vec{m}}$ & $m$ & $n$ & in & $\stackrel{2 n}{=}$ & $m$ & $m$ & $m$ & in & $m$ & - & $m$ & in & $\begin{array}{c}0 \\
\hat{n} \\
0 \\
i \\
i\end{array}$ & $\begin{array}{l}\text { 옹 } \\
\text { + } \\
\text { i }\end{array}$ & $\begin{array}{l}\text { mे } \\
\text { ô } \\
0\end{array}$ \\
\hline 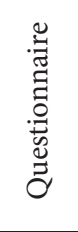 & $\neg$ & $\sim$ & $m$ & $H$ & in & 6 & 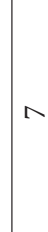 & $\infty$ & $a$ & 으 & $=$ & $\simeq$ & 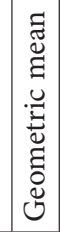 & 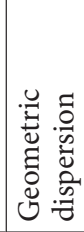 & 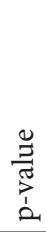 \\
\hline
\end{tabular}


(2) Company Status

The analysis performed using credit records is repeated using company status. The judgment of 12 experts is provided in Table 6.

Table 6. Judgments, geometric means, and $p$-value of company status criteria

\begin{tabular}{|c|c|c|c|}
\hline Questionnaire & B21/B22 & B21/B23 & B22/B23 \\
\hline 1 & 5 & 5 & 3 \\
\hline 2 & 5 & 5 & $1 / 5$ \\
\hline 3 & 4 & 5 & 3 \\
\hline 4 & 1 & 3 & $1 / 3$ \\
\hline 5 & $1 / 3$ & $1 / 5$ & $1 / 3$ \\
\hline 6 & 5 & 9 & $1 / 5$ \\
\hline 7 & 9 & 9 & $1 / 2$ \\
\hline 8 & 7 & 9 & $1 / 5$ \\
\hline 9 & 8 & 9 & 1 \\
\hline 10 & 5 & 5 & $1 / 3$ \\
\hline 11 & 7 & 5 & 0.5037 \\
\hline 12 & 3.1570 & 3.5569 & 2.2782 \\
\hline Geometric mean & 2.5626 & 2.4662 & 0.0145 \\
\hline Geometric dispersion & 0.0563 & 0.0375 & \\
\hline p-value & & & 5 \\
\hline
\end{tabular}

The pairwise judgment matrix is presented as follows:

$$
d_{x}=\left[\begin{array}{ccc}
1 & 3.1570 & 3.5569 \\
0.3168 & 1 & 0.5037 \\
0.2811 & 1.9853 & 1
\end{array}\right]
$$

From which priorities of company status criteria are obtained:

$$
W_{b 2}=\left(\begin{array}{c}
0.64211 \\
0.1505 \\
0.2284
\end{array}\right), \mathrm{CI}=0.03625, \mathrm{CR}=0.06250<0.1
$$

\subsection{Weights for quality credit ability}

(1) Product quality

Table 7 presents judgments, geometric means, geometric dispersion, and corresponding p-values for 12 experts. 


\begin{tabular}{|c|c|c|c|c|c|c|c|c|c|c|c|c|c|c|c|}
\hline $\begin{array}{l}\stackrel{n}{\tilde{n}} \\
\stackrel{\text { fr }}{m}\end{array}$ & $\neg$ & $\stackrel{10}{=}$ & $\stackrel{10}{=}$ & $N$ & $\stackrel{20}{=}$ & $N$ & -1 & $m$ & $N$ & $m$ & - & $\stackrel{\ln }{=}$ & $\begin{array}{c}1 \\
\hat{n} \\
\infty \\
\infty \\
0\end{array}$ & 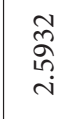 & $\begin{array}{l}0 \\
\text { ర్ర } \\
0 \\
0\end{array}$ \\
\hline $\begin{array}{l}\stackrel{n}{\tilde{n}} \\
\stackrel{m}{m} \\
\tilde{n}\end{array}$ & $\stackrel{\varrho}{=}$ & $\neg$ & $N$ & $N$ & $\stackrel{+}{\leftrightarrows}$ & $\sim$ & $a$ & $\sim$ & $N$ & $\neg$ & - & $\neg$ & $\begin{array}{c}\tilde{n} \\
\tilde{\delta} \\
\tilde{n} \\
-\end{array}$ & 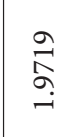 & \begin{tabular}{l}
0 \\
\hdashline \\
8 \\
0 \\
0
\end{tabular} \\
\hline $\begin{array}{l}\stackrel{\vec{m}}{m} \\
\stackrel{m}{m}\end{array}$ & $\stackrel{\varrho}{=}$ & $a$ & $N$ & $\stackrel{\mathrm{N}}{=}$ & $m$ & -7 & $\curvearrowright$ & $\stackrel{N}{=}$ & $\rightarrow$ & - & $m$ & in & 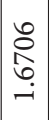 & 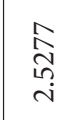 & 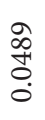 \\
\hline $\begin{array}{l}\stackrel{n}{\tilde{n}} \\
\underset{\tilde{N}}{\tilde{n}}\end{array}$ & - & - & -1 & $N$ & $m$ & $\sim$ & $\wedge$ & 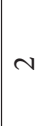 & $N$ & - & - & $\stackrel{m}{=}$ & \begin{tabular}{|l}
$\stackrel{0}{\infty}$ \\
$\stackrel{\infty}{+}$ \\
$\stackrel{+}{-}$
\end{tabular} & $\begin{array}{l}\stackrel{2}{\curvearrowright} \\
\stackrel{-}{\wedge}\end{array}$ & 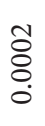 \\
\hline 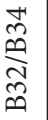 & $\stackrel{\varrho}{=}$ & $a$ & $m$ & $m$ & $\stackrel{m}{=}$ & $\sim$ & $m$ & $\sim$ & $N$ & $\neg$ & - & $m$ & 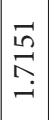 & $\begin{array}{l}10 \\
0 \\
0 \\
i \\
i\end{array}$ & 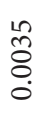 \\
\hline 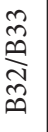 & $\neg$ & - & $m$ & $\sim$ & $\stackrel{\sim}{=}$ & $\sim$ & $\stackrel{10}{=}$ & $\sim$ & $\sim$ & - & $m$ & $\stackrel{m}{=}$ & $\begin{array}{l}2 \\
2 \\
\\
-\end{array}$ & $\begin{array}{l}\text { के } \\
\stackrel{8}{0} \\
\text { i }\end{array}$ & 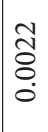 \\
\hline 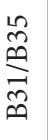 & $\neg$ & $\stackrel{n}{=}$ & in & in & - & $\wedge$ & $\wedge$ & in & $\curvearrowright$ & $m$ & - & $m$ & 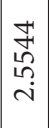 & $\begin{array}{l}\text { D } \\
\stackrel{\#}{+} \\
\stackrel{i}{i}\end{array}$ & $\begin{array}{c}\hat{\text { }} \\
\text { ô } \\
\dot{0}\end{array}$ \\
\hline$\underset{\ddot{n}}{\stackrel{+}{m}}$ & $m$ & $a$ & in & $\sim$ & in & in & in & $m$ & $m$ & $m$ & - & $\wedge$ & $\begin{array}{l}2 \\
\delta \\
0 \\
\dot{n} \\
\dot{1}\end{array}$ & $\begin{array}{l}0 \\
\infty \\
\infty \\
\\
-1\end{array}$ & $\begin{array}{l}8 \\
8 \\
8 \\
0\end{array}$ \\
\hline$\underset{m}{\stackrel{m}{\omega}}$ & $m$ & - & 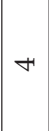 & $\sim$ & 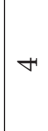 & $m$ & $\stackrel{10}{=}$ & $\sim$ & $m$ & $m$ & $m$ & in & 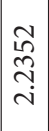 & 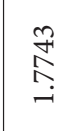 & 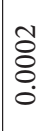 \\
\hline 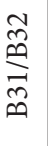 & $m$ & $\rightarrow$ & $m$ & H & $n$ & $m$ & -1 & 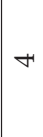 & $m$ & $m$ & - & $m$ & $\begin{array}{l}n \\
\tilde{\sigma} \\
\tilde{m} \\
\text { iv }\end{array}$ & 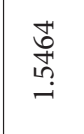 & $\begin{array}{l}8 \\
8 \\
8 \\
0\end{array}$ \\
\hline 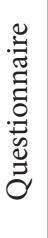 & $\neg$ & $v$ & $m$ & $r$ & in & 0 & $n$ & $\infty$ & $a$ & 으 & $\exists$ & $\simeq$ & 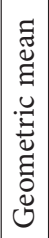 & 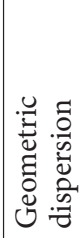 & 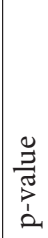 \\
\hline
\end{tabular}


The judgment matrix is presented as follows:

$$
d_{x}=\left[\begin{array}{ccccc}
1 & 2.3915 & 2.2352 & 3.6903 & 2.5544 \\
0.4182 & 1 & 1.1396 & 1.7151 & 1.4817 \\
0.4474 & 0.8775 & 1 & 1.6706 & 1.3032 \\
0.2710 & 0.5830 & 0.5986 & 1 & 0.8352 \\
0.3915 & 0.6749 & 0.7673 & 1.1973 & 1
\end{array}\right] .
$$

From which priorities of product quality criteria are obtained:

$$
W_{b 3}=\left(\begin{array}{c}
0.3948 \\
0.1871 \\
0.1742 \\
0.1082 \\
0.1357
\end{array}\right), \mathrm{CI}=0.002275, \mathrm{CR}=0.002031<0.1 .
$$

(2) Service quality

Table 8 shows judgments, geometric means, geometric dispersion, and corresponding p-values for 12 experts.

The judgment matrix is given as follows:

$$
d_{x}=\left[\begin{array}{lllllll}
1 & 1.1933 & 0.8302 & 0.7980 & 0.8613 & 0.5990 & 0.7764 \\
0.8380 & 1 & 1.2532 & 0.8745 & 1.1788 & 0.5126 & 0.8246 \\
1.2046 & 0.7980 & 1 & 1.3599 & 1.7327 & 0.5437 & 1.0243 \\
1.2532 & 1.1435 & 0.7354 & 1 & 2.1705 & 0.6703 & 1.1335 \\
1.1610 & 0.8483 & 0.5673 & 0.4607 & 1 & 0.3912 & 0.8154 \\
1.6695 & 1.9508 & 1.8394 & 1.4918 & 2.5560 & 1 & 1.8512 \\
1.2879 & 1.2128 & 0.9763 & 0.8822 & 1.2264 & 0.5402 & 1
\end{array}\right] .
$$

From which priorities of product quality criteria are obtained:

$$
W_{b 4}=\left(\begin{array}{c}
0.1172 \\
0.1238 \\
0.1442 \\
0.1499 \\
0.0972 \\
0.2333 \\
0.1343
\end{array}\right), \mathrm{CI}=0.01414, \mathrm{CR}=0.010714<0.1 .
$$




\begin{tabular}{|c|c|c|c|c|c|c|c|c|c|c|c|c|c|c|c|}
\hline 它 省 & in & $a$ & 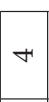 & - & $\stackrel{20}{=}$ & - & $a$ & - & - & in & - & - & $\begin{array}{l}\stackrel{1}{*} \\
\infty \\
\infty \\
-1\end{array}$ & $\begin{array}{l}\stackrel{H}{\sim} \\
\infty \\
0 \\
\sim \\
ن\end{array}$ & $\begin{array}{l}+1 \\
\stackrel{1}{0} \\
0 \\
0 \\
0\end{array}$ \\
\hline 焉年 & - & - & - & $\stackrel{\varrho}{=}$ & $\stackrel{m}{=}$ & 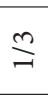 & 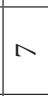 & - & $\stackrel{n}{=}$ & $\stackrel{n}{=}$ & - & $m$ & $\begin{array}{l}+1 \\
10 \\
\infty \\
0 \\
0\end{array}$ & $\begin{array}{l}\text { + } \\
\stackrel{5}{0} \\
\stackrel{i}{i}\end{array}$ & \begin{tabular}{l}
$\infty$ \\
\multirow{1}{*}{} \\
0 \\
0 \\
0
\end{tabular} \\
\hline 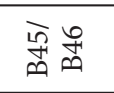 & $\stackrel{m}{=}$ & $\stackrel{a}{\lambda}$ & $m$ & $\stackrel{\sim}{=}$ & $\stackrel{+}{二}$ & $\stackrel{\mathrm{N}}{=}$ & $\stackrel{a}{=}$ & $\stackrel{\sim}{=}$ & $\stackrel{\beth}{\beth}$ & $\stackrel{n}{\rightleftharpoons}$ & - & $\stackrel{n}{=}$ & $\begin{array}{l}\text { ते } \\
\text { กे } \\
0\end{array}$ & 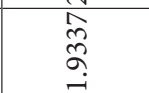 & $\begin{array}{l}\overline{7} \\
\overline{8} \\
0\end{array}$ \\
\hline 店拿 & - & -7 & $m$ & $\stackrel{\sim}{\beth}$ & -1 & - & $m$ & $\neg$ & - & $\stackrel{m}{=}$ & - & $m$ & $\stackrel{n}{m}$ & $\begin{array}{l}\infty \\
0 \\
0 \\
0 \\
-\end{array}$ & 追 \\
\hline 多 品 & $\stackrel{m}{=}$ & - & $\stackrel{\curvearrowright}{=}$ & $\sim$ & 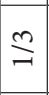 & - & $\stackrel{9}{=}$ & - & - & $\stackrel{\leftrightarrow}{\rightleftharpoons}$ & - & in & $\begin{array}{l}0 \\
0 \\
\hat{0} \\
0\end{array}$ & 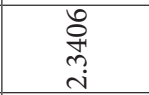 & 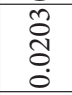 \\
\hline 焉吊 & - & $a$ & 6 & $m$ & $m$ & $m$ & $\stackrel{n}{=}$ & $\stackrel{\sim}{=}$ & $m$ & $m$ & $\neg$ & in & $\stackrel{2}{\stackrel{2}{2}}$ & 离 & $\begin{array}{l}0 \\
0 \\
0 \\
0 \\
0 \\
0\end{array}$ \\
\hline 可拿 & $\stackrel{m}{=}$ & $\rightarrow$ & $\stackrel{\varrho}{=}$ & $N$ & $\sim$ & -1 & $m$ & $\neg$ & - & $\stackrel{\Re}{=}$ & - & $m$ & $\underset{\mathfrak{H}}{\stackrel{3}{\sigma}}$ & 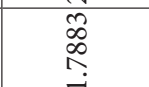 & ఫิ \\
\hline 商占 & $\stackrel{20}{=}$ & $\rightarrow$ & $\stackrel{10}{=}$ & - & $\stackrel{\sim}{\underset{ }{\sim}}$ & -1 & $\stackrel{a}{=}$ & $\stackrel{\sim}{=}$ & - & $\stackrel{n}{=}$ & - & $m$ & 命 & ஓి & ڤू \\
\hline 商 & $\stackrel{m}{=}$ & - & $m$ & $m$ & $\theta$ & $m$ & - & - & $m$ & in & $\stackrel{\curvearrowright}{=}$ & in & స్ & $\vec{m}$ & $\begin{array}{l}\frac{n}{n} \\
\stackrel{1}{0}\end{array}$ \\
\hline क্ & $\stackrel{m}{=}$ & - & in & $m$ & $\sim$ & $N$ & $\neg$ & $\neg$ & $\sim$ & - & $\stackrel{\sim}{=}$ & $m$ & ने & $\frac{v}{2}$ & $\frac{10}{8}$ \\
\hline 辛告 & $\stackrel{m}{=}$ & - & $\stackrel{m}{=}$ & $\stackrel{\varrho}{=}$ & $\sim$ & $N$ & - & - & $\sim$ & $\neg$ & $\neg$ & $\stackrel{\Re}{=}$ & 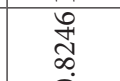 & ঐे & ôे \\
\hline ঐా & $\stackrel{20}{=}$ & - & $\stackrel{20}{=}$ & $\stackrel{m}{=}$ & $\rightarrow$ & $N$ & $\stackrel{2}{=}$ & $\stackrel{\sim}{=}$ & $\sim$ & $\stackrel{m}{=}$ & - & $\stackrel{n}{=}$ & 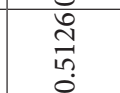 & $\begin{array}{l}\infty \\
\infty \\
2 \\
\stackrel{1}{1}\end{array}$ & $\begin{array}{l}0 \\
8 \\
0 \\
0\end{array}$ \\
\hline 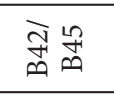 & $\stackrel{m}{=}$ & - & $m$ & $m$ & 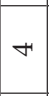 & $N$ & $\stackrel{n}{=}$ & $\stackrel{\mathrm{N}}{=}$ & $\sim$ & $m$ & $\neg$ & $\stackrel{-}{\sim}$ & 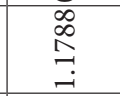 & $\begin{array}{l}\text { ते } \\
\text { तె } \\
\text { i }\end{array}$ & $\begin{array}{l}\tilde{n} \\
\vdots \\
0\end{array}$ \\
\hline ঙ্ & $\stackrel{m}{=}$ & - & $\stackrel{10}{=}$ & -7 & $m$ & - & $\stackrel{n}{=}$ & - & - & $m$ & $m$ & $\stackrel{m}{=}$ & 啇 & $\begin{array}{l}\text { I } \\
\text { İ } \\
\text { i }\end{array}$ & $\begin{array}{l}0 \\
0 \\
0 \\
0 \\
0\end{array}$ \\
\hline ঙ্ & - & - & in & $\stackrel{\sim}{=}$ & $N$ & $N$ & $\stackrel{m}{=}$ & - & $\sim$ & $m$ & $m$ & $\stackrel{+}{=}$ & กี & $\begin{array}{l}\stackrel{N}{\infty} \\
\stackrel{\sim}{\sim} \\
\sim\end{array}$ & $\begin{array}{l}\text { L } \\
\stackrel{2}{0} \\
0 \\
0\end{array}$ \\
\hline 学告 & $\stackrel{2}{=}$ & - & $m$ & $\stackrel{\cong}{=}$ & $\stackrel{10}{=}$ & $N$ & - & $\stackrel{\sim}{\stackrel{N}{\prime}}$ & $\sim$ & $\neg$ & $m$ & $\stackrel{10}{2}$ & $\begin{array}{l}\text { ț } \\
\stackrel{1}{\hat{~}} \\
0\end{array}$ & 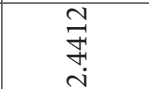 & $\begin{array}{l}\text { Ln } \\
\text { ôे } \\
0 \\
0\end{array}$ \\
\hline 章㨁 & $\stackrel{0}{-1}$ & - & $\stackrel{20}{=}$ & - & $\stackrel{10}{=}$ & N & $\stackrel{m}{=}$ & - & $\sim$ & $\stackrel{m}{=}$ & $m$ & $\stackrel{\text { in }}{=}$ & 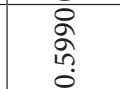 & $\begin{array}{l}\overrightarrow{0} \\
\text { ก } \\
\text { i }\end{array}$ & $\begin{array}{l}0 \\
0 \\
0 \\
0 \\
0 \\
0\end{array}$ \\
\hline 学嵒 & $\stackrel{m}{=}$ & - & $\stackrel{m}{=}$ & $\rightarrow$ & $\stackrel{m}{=}$ & $m$ & $\stackrel{m}{=}$ & $\stackrel{\sim}{=}$ & $m$ & $m$ & $m$ & $\stackrel{m}{=}$ & $\begin{array}{l}m \\
b \\
0 \\
0\end{array}$ & $\begin{array}{l}\vec{n} \\
\overrightarrow{7} \\
i\end{array}$ & 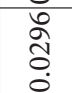 \\
\hline 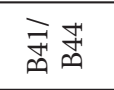 & $\stackrel{m}{=}$ & - & 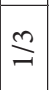 & $m$ & $\stackrel{10}{=}$ & - & $\stackrel{n}{=}$ & - & - & in & $m$ & $\stackrel{10}{=}$ & $\begin{array}{l}0 \\
0 \\
2 \\
0 \\
0\end{array}$ & 号 & $\begin{array}{l}n \\
2 \\
n \\
0 \\
0 \\
0\end{array}$ \\
\hline 糔䍃 & - & - & $m$ & $\stackrel{N}{=}$ & $\stackrel{0}{=}$ & - & $\stackrel{n}{=}$ & - & $\neg$ & $m$ & $m$ & $\triangleq$ & $\begin{array}{l}\text { ते } \\
\infty \\
\infty \\
0 \\
0\end{array}$ & $\begin{array}{l}\stackrel{2}{a} \\
\stackrel{i}{i}\end{array}$ & $\begin{array}{l}\text { Tे } \\
0 \\
0 \\
0 \\
0\end{array}$ \\
\hline$\vec{\forall}$ & $\stackrel{n}{=}$ & - & 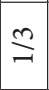 & $\rightarrow$ & $\stackrel{20}{=}$ & in & - & $m$ & in & in & $m$ & $\stackrel{m}{=}$ & $\stackrel{m}{\stackrel{n}{=}}$ & $\begin{array}{l}\stackrel{+}{m} \\
\infty \\
\stackrel{\infty}{1} \\
\text { i }\end{array}$ & 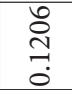 \\
\hline 岂完.气 & $\neg$ & $N$ & $m$ & $\forall$ & in & 6 & $\wedge$ & $\infty$ & $a$ & 으 & $\Xi$ & $\simeq$ & 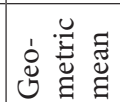 & 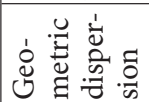 & 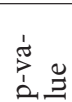 \\
\hline
\end{tabular}




\subsection{Weights for quality credit basis}

(1) Industry environment

Table 9 presents the judgments, geometric means, geometric dispersion, and corresponding p-values for 12 experts.

Table 9. Judgments, geometric means, and p-value of industry environment criteria

\begin{tabular}{|c|c|c|c|c|c|c|}
\hline Questionnaire & B51/B52 & B51/B53 & B51/B54 & B52/B53 & B52/B54 & B53/B54 \\
\hline 1 & $1 / 3$ & 1 & 3 & 1 & 3 & 3 \\
\hline 2 & 3 & 1 & 3 & 1 & 3 & 3 \\
\hline 3 & 3 & $1 / 3$ & $1 / 5$ & $1 / 5$ & $1 / 5$ & 5 \\
\hline 4 & 3 & 3 & 3 & $1 / 2$ & 3 & $1 / 2$ \\
\hline 5 & 5 & 3 & 3 & 3 & 3 & 1 \\
\hline 6 & 9 & 1 & 7 & $1 / 9$ & 5 & 7 \\
\hline 7 & 1 & $1 / 5$ & 1 & $1 / 5$ & 1 & 7 \\
\hline 8 & 5 & 2 & 5 & $1 / 4$ & 5 & 5 \\
\hline 9 & 9 & 1 & 7 & $1 / 9$ & 5 & 7 \\
\hline 10 & 1 & 1 & 3 & 1 & 3 & 3 \\
\hline 11 & $1 / 3$ & 1 & $1 / 5$ & 1 & $1 / 5$ & $1 / 5$ \\
\hline 12 & 5 & $1 / 3$ & 5 & $1 / 3$ & 5 & 7 \\
\hline $\begin{array}{l}\text { Geometric } \\
\text { mean }\end{array}$ & 2.3634 & 0.9265 & 2.1860 & 0.4459 & 2.0668 & 2.7173 \\
\hline $\begin{array}{l}\text { Geometric } \\
\text { dispersion }\end{array}$ & 2.5590 & 1.8153 & 2.5282 & 2.3996 & 2.4583 & 2.3410 \\
\hline p-value & 0.0555 & 0.0003 & 0.0490 & 0.0275 & 0.0362 & 0.0204 \\
\hline
\end{tabular}

The judgment matrix is presented as follows:

$$
d_{x}=\left[\begin{array}{cccc}
1 & 2.3634 & 0.9265 & 2.1860 \\
0.4231 & 1 & 0.4459 & 2.0668 \\
1.0793 & 2.2428 & 1 & 2.7173 \\
0.4575 & 0.4838 & 0.3680 & 1
\end{array}\right] .
$$

From which priorities of industry environment criteria are obtained:

$$
W_{b 5}=\left(\begin{array}{l}
0.3363 \\
0.1814 \\
0.3600 \\
0.1222
\end{array}\right), \mathrm{CI}=0.02040, \mathrm{CR}=0.02267<0.1
$$




\subsection{Criteria weights}

Table 10 shows the judgments, geometric means, geometric dispersion, and corresponding p-values for 12 experts.

Table 10. Judgments, geometric means, and $p$-value of criteria

\begin{tabular}{|c|c|c|c|c|c|c|c|c|c|c|}
\hline $\begin{array}{c}\text { Question- } \\
\text { naire }\end{array}$ & $\mathrm{B} 1 / \mathrm{B} 2$ & $\mathrm{~B} 1 / \mathrm{B} 3$ & $\mathrm{~B} 1 / \mathrm{B} 4$ & $\mathrm{~B} 1 / \mathrm{B} 5$ & $\mathrm{~B} 2 / \mathrm{B} 3$ & $\mathrm{~B} 2 / \mathrm{B} 4$ & $\mathrm{~B} 2 / \mathrm{B} 5$ & $\mathrm{~B} 3 / \mathrm{B} 4$ & $\mathrm{~B} 3 / \mathrm{B} 5$ & $\mathrm{~B} 4 / \mathrm{B} 5$ \\
\hline 1 & $1 / 5$ & $1 / 3$ & 3 & $1 / 3$ & 3 & 5 & 3 & 1 & 3 & 1 \\
\hline 2 & 1 & 1 & 1 & 3 & $1 / 5$ & $1 / 5$ & 3 & 1 & 1 & 1 \\
\hline 3 & $1 / 3$ & 2 & $1 / 4$ & 3 & 4 & 5 & 3 & 3 & 3 & 1 \\
\hline 4 & $1 / 5$ & $1 / 7$ & $1 / 5$ & 5 & 2 & 2 & 2 & $1 / 5$ & 2 & 2 \\
\hline 5 & 5 & $1 / 5$ & $1 / 3$ & 5 & $1 / 3$ & $1 / 4$ & 3 & 3 & 3 & 5 \\
\hline 6 & 3 & 1 & 4 & $1 / 5$ & $1 / 2$ & $1 / 3$ & $1 / 5$ & $1 / 2$ & $1 / 5$ & $1 / 5$ \\
\hline 7 & 3 & $1 / 5$ & $1 / 3$ & 5 & $1 / 9$ & $1 / 7$ & 2 & 2 & 3 & 7 \\
\hline 8 & 5 & 1 & 3 & $1 / 2$ & 1 & $1 / 3$ & $1 / 3$ & $1 / 3$ & $1 / 3$ & $1 / 2$ \\
\hline 9 & 3 & 3 & 3 & $1 / 5$ & $1 / 2$ & $1 / 2$ & $1 / 5$ & $1 / 2$ & $1 / 5$ & $1 / 5$ \\
\hline 10 & 3 & 1 & 1 & 3 & $1 / 3$ & $1 / 3$ & $1 / 3$ & 1 & 3 & 1 \\
\hline 11 & 5 & 1 & 1 & 3 & $1 / 3$ & $1 / 3$ & 1 & 1 & 1 & 1 \\
\hline 12 & 5 & $1 / 3$ & 3 & 5 & $1 / 7$ & $1 / 3$ & $1 / 3$ & 5 & 3 & $1 / 3$ \\
\hline $\begin{array}{l}\text { Geomet- } \\
\text { ric mean }\end{array}$ & 1.7210 & 0.6286 & 1.0502 & 1.6244 & 0.5462 & 0.5481 & 0.9407 & 1.0344 & 1.2805 & 0.9385 \\
\hline $\begin{array}{l}\text { Geomet- } \\
\text { ric disper- } \\
\text { sion }\end{array}$ & 2.6882 & 1.9142 & 2.5159 & 2.3843 & 1.9492 & 2.0721 & 2.8146 & 2.0698 & 2.5235 & 2.2095 \\
\hline p-value & 0.0891 & 0.0009 & 0.0466 & 0.0254 & 0.0013 & 0.0037 & 0.1321 & 0.0036 & 0.0480 & 0.0095 \\
\hline
\end{tabular}

The judgment matrix is presented as follows:

$$
d_{x}=\left[\begin{array}{ccccc}
1 & 1.7210 & 0.6286 & 1.0502 & 1.6244 \\
0.5811 & 1 & 0.5462 & 0.5481 & 0.9407 \\
1.5907 & 1.8307 & 1 & 1.0344 & 1.2805 \\
0.9522 & 1.8245 & 0.9668 & 1 & 0.9385 \\
0.6156 & 1.0631 & 0.7809 & 1.0656 & 1
\end{array}\right] .
$$

From which the priorities of criteria are obtained:

$$
W_{a}=\left(\begin{array}{l}
0.2213 \\
0.1350 \\
0.2563 \\
0.2134 \\
0.1739
\end{array}\right), \mathrm{CI}=0.017, \mathrm{CR}=0.015067<0.1
$$

Accordingly, priorities for the quality credit evaluation system can be tabulated as shown in Table 11. 
Table 11. Quality credit evaluation system

\begin{tabular}{|c|c|c|c|c|}
\hline Criteria & $\begin{array}{l}\text { Criteria } \\
\text { Weights }\end{array}$ & Sub-criteria & $\begin{array}{l}\text { Sub-criteria } \\
\text { Weights }\end{array}$ & $\begin{array}{c}\text { Global } \\
\text { Weights }\end{array}$ \\
\hline \multirow{6}{*}{$\begin{array}{l}\text { B1 Credit } \\
\text { records }\end{array}$} & \multirow{6}{*}{0.2213} & B11 The record of consumer complaints & 0.0908 & 0.0201 \\
\hline & & B12 Customer satisfaction & 0.0662 & 0.0147 \\
\hline & & $\begin{array}{l}\text { B13 The record of quality illegal or quality } \\
\text { default }\end{array}$ & 0.2518 & 0.0557 \\
\hline & & B14 False propaganda of product quality & 0.1168 & 0.0258 \\
\hline & & B15 Quality accident & 0.371 & 0.0821 \\
\hline & & B16 Other disciplinary record & 0.1033 & 0.0229 \\
\hline \multirow{3}{*}{$\begin{array}{c}\text { B2 } \\
\text { Company } \\
\text { status }\end{array}$} & \multirow{3}{*}{0.1350} & B21 Operating legitimacy & 0.6211 & 0.0838 \\
\hline & & $\begin{array}{l}\text { B22 The nature of the enterprise and the } \\
\text { status of the industry }\end{array}$ & 0.1505 & 0.0203 \\
\hline & & B23 Quality honorary title & 0.2284 & 0.0308 \\
\hline \multirow{5}{*}{$\begin{array}{l}\text { B3 Quality } \\
\text { of product }\end{array}$} & \multirow{5}{*}{0.2563} & B31 Qualification rate of product supervise & 0.3948 & 0.1012 \\
\hline & & B32 The level of product technology(R\&D) & 0.1871 & 0.0480 \\
\hline & & B33 Standard using rate & 0.1742 & 0.0446 \\
\hline & & B34 Brand Building & 0.1082 & 0.0277 \\
\hline & & B35 Quality certification & 0.1357 & 0.0348 \\
\hline \multirow{7}{*}{$\begin{array}{l}\text { B4 Quality } \\
\text { of service }\end{array}$} & \multirow{7}{*}{0.2134} & B41 Service staff attitude & 0.1172 & 0.0250 \\
\hline & & B42 Service staff professional & 0.1238 & 0.0264 \\
\hline & & B43 Response time & 0.1442 & 0.0308 \\
\hline & & B44 The ability of complaint solving & 0.1499 & 0.0320 \\
\hline & & B45 The ability of logistics and delivery & 0.0972 & 0.0207 \\
\hline & & B46 Pay security & 0.2333 & 0.0498 \\
\hline & & B47 After-sales service & 0.1343 & 0.0287 \\
\hline \multirow{4}{*}{$\begin{array}{l}\text { B5 Industry } \\
\text { environment }\end{array}$} & \multirow{4}{*}{0.1739} & $\begin{array}{l}\text { B51 The mechanism of industry supervision } \\
\text { and punishment }\end{array}$ & 0.3363 & 0.0585 \\
\hline & & B52 Industry standard system & 0.1814 & 0.0315 \\
\hline & & B53 Industry legal completeness & 0.36 & 0.0626 \\
\hline & & B54 Industry trends & 0.1222 & 0.0213 \\
\hline
\end{tabular}

\section{Example}

To illustrate the presented evaluation methodology, data from Consumer Reports (www. consumerreports.org) for six companies that do business in the United States through ecommerce are collected. These six companies operate the largest shopping websites: Costco, LLBean, Amazon, eBay, ProFlowers, and Ticketmaster. The survey scores include value, quality, navigation, checkout, shipping, and customer support. Each item is scored from worst to best on a 1 to 5 Likert point scale.

Because the data required for this evaluation system do not exist or are not available in the US market, the survey criteria as shown in Table 12. The survey and reader scores are presented in Table 13. 
Table 12. Quality credit criteria mapped to US survey criteria

\begin{tabular}{|l|c|l|}
\hline \multicolumn{1}{|c|}{ Criteria } & Priorities & \multicolumn{1}{c|}{ Survey Criteria } \\
\hline B1 Credit records & 0.2213 & Customer Support \\
\hline B2 Company status & 0.1350 & Operating legitimacy \\
\hline B3 Quality of product & \multirow{2}{*}{0.2563} & Value \\
\cline { 3 - 3 } & \multirow{2}{*}{ B4 Quality of service } & Quality \\
\hline B5 Industry environment & 0.2134 & Navigation \\
\cline { 3 - 4 } & & Checkout \\
\cline { 2 - 3 } & 0.1739 & Shipping \\
\hline
\end{tabular}

Table 13. Survey and reader scores from Consumer Reports

\begin{tabular}{|c|l|c|c|c|c|c|c|c|}
\hline & Website & Value & Quality & $\begin{array}{c}\text { Navi- } \\
\text { gation }\end{array}$ & Checkout & Shipping & $\begin{array}{c}\text { Customer } \\
\text { Support }\end{array}$ & $\begin{array}{c}\text { Reader } \\
\text { score }\end{array}$ \\
\hline 1 & Costco.com & 4 & 4 & 4 & 4 & 4 & 4 & 91 \\
\hline 2 & L.L.Bean.com & 4 & 5 & 4 & 4 & 4 & 5 & 90 \\
\hline 3 & Amazon.com & 4 & 4 & 4 & 4 & 3 & 3 & 87 \\
\hline 4 & eBay.com & 3 & 3 & 4 & 4 & 2 & 2 & 85 \\
\hline 5 & ProFlowers.com & 2 & 3 & 3 & 3 & 1 & 3 & 79 \\
\hline 6 & Ticketmaster.com & 1 & 3 & 2 & 1 & 1 & 1 & 74 \\
\hline
\end{tabular}

Using the scorecards described in the Appendix, the 1-5 scale is transformed into a 1-100 scale. The results are provided in Table 14.

Table 14. Survey scores on a 1-100 scale

\begin{tabular}{|l|l|c|c|c|c|c|c|c|c|}
\hline Website & Value & Quality & $\begin{array}{c}\text { Navi- } \\
\text { gation }\end{array}$ & $\begin{array}{c}\text { Check- } \\
\text { out }\end{array}$ & $\begin{array}{c}\text { Ship- } \\
\text { ping }\end{array}$ & $\begin{array}{c}\text { Custo- } \\
\text { mer } \\
\text { Support }\end{array}$ & $\begin{array}{c}\text { Reader } \\
\text { score }\end{array}$ & $\begin{array}{c}\text { Quality } \\
\text { Credit } \\
\text { Scores }\end{array}$ \\
\hline 1 & Costco.com & 80 & 80 & 80 & 80 & 80 & 80 & 91 & 86.1700 \\
\hline 2 & L.L.Bean.com & 80 & 100 & 80 & 80 & 80 & 100 & 90 & 93.1590 \\
\hline 3 & Amazon.com & 80 & 80 & 80 & 80 & 70 & 70 & 87 & 83.2457 \\
\hline 4 & eBay.com & 70 & 70 & 80 & 80 & 60 & 60 & 85 & 77.7583 \\
\hline 5 & ProFlowers.com & 60 & 70 & 70 & 70 & 40 & 70 & 79 & 75.8445 \\
\hline 6 & Ticketmaster.com & 40 & 70 & 60 & 40 & 40 & 40 & 74 & 63.7972 \\
\hline
\end{tabular}

Next, using the priorities from Table 12 and the scores from Table 13, the quality credit scores for these six companies selected are computed (Table 15).

In order to make the result more practical, the quality credit scores are then transformed into a label scale (Table 16). 
Table 15. Quality credit scores of six US companies

\begin{tabular}{|c|c|c|c|c|c|c|c|c|}
\hline Criteria & Weights & Sub-criteria & Costco & LLBean & Amazon & eBay & $\begin{array}{c}\text { Pro- } \\
\text { Flowers }\end{array}$ & $\begin{array}{l}\text { Ticket- } \\
\text { master }\end{array}$ \\
\hline $\begin{array}{l}\text { B1 Credit } \\
\text { records }\end{array}$ & 0.2213 & $\begin{array}{l}\text { Customer } \\
\text { Support }\end{array}$ & 80 & 100 & 70 & 60 & 70 & 40 \\
\hline $\begin{array}{l}\text { B2 } \\
\text { Company } \\
\text { status }\end{array}$ & 0.1350 & $\begin{array}{l}\text { Operating } \\
\text { legitimacy }\end{array}$ & 100 & 100 & 100 & 100 & 100 & 100 \\
\hline \multirow{2}{*}{$\begin{array}{l}\text { B3 Quality } \\
\text { of product }\end{array}$} & \multirow{2}{*}{0.2563} & Value & 80 & 80 & 80 & 70 & 60 & 40 \\
\hline & & Quality & 80 & 100 & 80 & 70 & 70 & 70 \\
\hline \multirow{3}{*}{$\begin{array}{l}\text { B4 Quality } \\
\text { of service }\end{array}$} & \multirow{3}{*}{0.2134} & Navigation & 80 & 80 & 80 & 80 & 70 & 60 \\
\hline & & Checkout & 80 & 80 & 80 & 80 & 70 & 40 \\
\hline & & Shipping & 80 & 80 & 70 & 60 & 40 & 40 \\
\hline $\begin{array}{l}\text { B5 Industry } \\
\text { environment }\end{array}$ & 0.1739 & $\begin{array}{l}\text { Industry } \\
\text { trends }\end{array}$ & 100 & 100 & 100 & 100 & 100 & 100 \\
\hline \multicolumn{3}{|l|}{ Final score } & 86.1700 & 93.1590 & 83.2457 & 77.7583 & 75.8445 & 63.7972 \\
\hline \multicolumn{3}{|c|}{ Quality Credit Level } & $\mathrm{AA}$ & AAA & AA & $\mathrm{A}$ & $\mathrm{A}$ & $\mathrm{B}$ \\
\hline
\end{tabular}

Table 16. Quality credit level

\begin{tabular}{|c|c|l|}
\hline $\begin{array}{c}\text { Credit } \\
\text { Level }\end{array}$ & Scoring & \multicolumn{1}{|c|}{ Level description } \\
\hline AAA & $>90$ marks & $\begin{array}{l}\text { The company has an excellent credit record, product quality, service quality, } \\
\text { and industry environment. It complies with the law and fulfils contracts and } \\
\text { has numerous awards }\end{array}$ \\
\hline AA & $\begin{array}{c}80-90 \\
\text { marks }\end{array}$ & $\begin{array}{l}\text { The company has a very good credit record, product quality, service quality, } \\
\text { and industry environment. It has few legal and contract violations, and it } \\
\text { also has numerous awards }\end{array}$ \\
\hline A & $\begin{array}{c}70-80 \\
\text { marks }\end{array}$ & $\begin{array}{l}\text { The company has a good credit record, product quality, service quality, and } \\
\text { industry environment. It has few legal and contract violations, and it also has } \\
\text { a few awards }\end{array}$ \\
\hline B & $\begin{array}{l}60-70 \\
\text { marks }\end{array}$ & $\begin{array}{l}\text { The company has an average credit record, product quality, service quality, } \\
\text { and industry environment. It has a few legal and contract violations, and it } \\
\text { also has a few awards }\end{array}$ \\
\hline Darks & $\begin{array}{l}\text { The company has a not so good credit record, quality of product, quality of } \\
\text { service and industry environment. It has a few legal and contract violations, } \\
\text { and it also has few awards }\end{array}$ \\
\hline 40 marks & $\begin{array}{l}\text { The company has a bad credit record, product quality, service quality, and } \\
\text { industry environment. It has numerous legal and contract violations, and it } \\
\text { also has no awards }\end{array}$ \\
\hline
\end{tabular}

To implement the proposed quality credit evaluation system, there is the information for all companies being evaluated in all dimensions described in the Appendix must be obtained. Table 17 provides an example of three fictitious companies used to illustrate the proposed system. 
Table 17. Example of the quality credit evaluation system

\begin{tabular}{|c|c|c|c|c|c|c|c|c|c|}
\hline \multirow{2}{*}{$\begin{array}{l}\text { Cri- } \\
\text { teria }\end{array}$} & \multirow[b]{2}{*}{ Weights } & \multirow[b]{2}{*}{ Sub-criteria } & \multirow[b]{2}{*}{ Weights } & \multicolumn{2}{|c|}{ A business } & \multicolumn{2}{|c|}{ B business } & \multicolumn{2}{|c|}{ C business } \\
\hline & & & & Score & $\begin{array}{l}\text { Final } \\
\text { score }\end{array}$ & Score & $\begin{array}{l}\text { Final } \\
\text { score }\end{array}$ & Score & $\begin{array}{l}\text { Final } \\
\text { score }\end{array}$ \\
\hline \multirow{6}{*}{$\begin{array}{l}\text { B1 } \\
\text { Credit } \\
\text { records }\end{array}$} & \multirow{6}{*}{0.2213} & $\begin{array}{l}\text { B11 The record of } \\
\text { consumer complaints }\end{array}$ & 0.0908 & 95 & 8.626 & 75 & 6.81 & 50 & 4.54 \\
\hline & & $\begin{array}{l}\text { B12 Customer } \\
\text { satisfaction }\end{array}$ & 0.0662 & 95 & 6.289 & 70 & 4.634 & 45 & 2.979 \\
\hline & & $\begin{array}{l}\text { B13 The record of } \\
\text { quality illegal or } \\
\text { quality default }\end{array}$ & 0.2518 & 85 & 21.403 & 70 & 17.626 & 50 & 12.59 \\
\hline & & $\begin{array}{l}\text { B14 False } \\
\text { propaganda of } \\
\text { product quality }\end{array}$ & 0.1168 & 100 & 11.68 & 70 & 8.176 & 35 & 4.088 \\
\hline & & B15 Quality accident & 0.3710 & 95 & 35.245 & 82 & 30.422 & 40 & 14.84 \\
\hline & & $\begin{array}{l}\text { B16 Other } \\
\text { disciplinary record }\end{array}$ & 0.1033 & 100 & 10.33 & 80 & 8.264 & 50 & 5.165 \\
\hline \multirow{3}{*}{$\begin{array}{l}\text { B2 } \\
\text { Com- } \\
\text { pany } \\
\text { status }\end{array}$} & \multirow{3}{*}{0.1350} & $\begin{array}{l}\text { B21 Operating } \\
\text { legitimacy }\end{array}$ & 0.6211 & 95 & 59.0045 & 75 & 46.5825 & 50 & 31.055 \\
\hline & & $\begin{array}{l}\text { B22 The nature of } \\
\text { the enterprise and } \\
\text { the status of the } \\
\text { industry }\end{array}$ & 0.1505 & 90 & 13.545 & 80 & 12.04 & 35 & 5.2675 \\
\hline & & $\begin{array}{l}\text { B23 Quality } \\
\text { honorary title }\end{array}$ & 0.2284 & 90 & 20.556 & 75 & 17.13 & 40 & 9.136 \\
\hline \multirow{5}{*}{$\begin{array}{l}\text { B3 } \\
\text { Quality } \\
\text { of pro- } \\
\text { duct }\end{array}$} & \multirow{5}{*}{0.2563} & $\begin{array}{l}\text { B31 Qualification } \\
\text { rate of product } \\
\text { supervise }\end{array}$ & 0.3948 & 95 & 37.506 & 69 & 27.2412 & 50 & 19.74 \\
\hline & & $\begin{array}{l}\text { B32 The level } \\
\text { of product } \\
\text { technology }(\mathrm{R} \& \mathrm{D})\end{array}$ & 0.1871 & 90 & 16.839 & 70 & 13.097 & 50 & 9.355 \\
\hline & & $\begin{array}{l}\text { B33 Standard using } \\
\text { rate }\end{array}$ & 0.1742 & 85 & 14.807 & 76 & 13.2392 & 55 & 9.581 \\
\hline & & B34 Brand Building & 0.1082 & 85 & 9.197 & 80 & 8.656 & 45 & 4.869 \\
\hline & & $\begin{array}{l}\text { B35 Quality } \\
\text { certification }\end{array}$ & 0.1357 & 90 & 12.213 & 90 & 12.213 & 40 & 5.428 \\
\hline \multirow{7}{*}{$\begin{array}{l}\text { B4 } \\
\text { Quality } \\
\text { of ser- } \\
\text { vice }\end{array}$} & \multirow{7}{*}{0.2134} & $\begin{array}{l}\text { B41 Service staff } \\
\text { attitude }\end{array}$ & 0.1172 & 90 & 10.548 & 80 & 9.376 & 60 & 7.032 \\
\hline & & $\begin{array}{l}\text { B42 Service staff } \\
\text { professional }\end{array}$ & 0.1238 & 90 & 11.142 & 75 & 9.285 & 60 & 7.428 \\
\hline & & B43 Response time & 0.1442 & 95 & 13.699 & 75 & 10.815 & 60 & 8.652 \\
\hline & & $\begin{array}{l}\text { B44 The ability of } \\
\text { complaint solving }\end{array}$ & 0.1499 & 90 & 13.491 & 75 & 11.2425 & 70 & 10.493 \\
\hline & & $\begin{array}{l}\text { B45 The ability of } \\
\text { logistics and delivery }\end{array}$ & 0.0972 & 100 & 9.72 & 75 & 7.29 & 65 & 6.318 \\
\hline & & B46 Pay security & 0.2333 & 100 & 23.33 & 80 & 18.664 & 65 & 15.1645 \\
\hline & & $\begin{array}{l}\text { B47 After-sales } \\
\text { service }\end{array}$ & 0.1343 & 95 & 12.7585 & 75 & 10.0725 & 60 & 8.058 \\
\hline
\end{tabular}


End of Table 17

\begin{tabular}{|c|c|c|c|c|c|c|c|c|c|}
\hline \multirow{2}{*}{$\begin{array}{l}\text { Cri- } \\
\text { teria }\end{array}$} & \multirow[b]{2}{*}{ Weights } & \multirow[b]{2}{*}{ Sub-criteria } & \multirow[b]{2}{*}{ Weights } & \multicolumn{2}{|c|}{ A business } & \multicolumn{2}{|c|}{ B business } & \multicolumn{2}{|c|}{$\mathrm{C}$ business } \\
\hline & & & & Score & $\begin{array}{l}\text { Final } \\
\text { score }\end{array}$ & Score & $\begin{array}{l}\text { Final } \\
\text { score }\end{array}$ & Score & $\begin{array}{l}\text { Final } \\
\text { score }\end{array}$ \\
\hline \multirow{4}{*}{$\begin{array}{l}\text { B5 } \\
\text { Indus- } \\
\text { try } \\
\text { envi- } \\
\text { ron- } \\
\text { ment }\end{array}$} & \multirow{4}{*}{0.1739} & $\begin{array}{l}\text { B51 The mechanism } \\
\text { of industry } \\
\text { supervision and } \\
\text { punishment }\end{array}$ & 0.3363 & 85 & 28.5855 & 80 & 26.904 & 55 & 18.4965 \\
\hline & & $\begin{array}{l}\text { B52 Industry } \\
\text { standard system }\end{array}$ & 0.1814 & 85 & 15.419 & 80 & 14.512 & 60 & 10.884 \\
\hline & & $\begin{array}{l}\text { B53 Industry legal } \\
\text { completeness }\end{array}$ & 0.3600 & 95 & 34.2 & 80 & 28.8 & 60 & 21.6 \\
\hline & & B54 Industry trends & 0.1222 & 95 & 11.609 & 80 & 9.776 & 60 & 7.332 \\
\hline $\begin{array}{l}\text { A busi- } \\
\text { ness's } \\
\text { total } \\
\text { score }\end{array}$ & \multicolumn{9}{|c|}{$\begin{array}{l}93.573 \times 0.2213+93.1055 \times 0.135+90.562 \times 0.2563+94.6885 \times 0.2134+89.8135 \times \\
0.1739=92.313\end{array}$} \\
\hline $\begin{array}{l}\text { B busi- } \\
\text { ness's } \\
\text { total } \\
\text { score }\end{array}$ & \multicolumn{9}{|c|}{$\begin{array}{l}75.932 \times 0.2213+75.7525 \times 0.1350+74.4464 \times 0.2563+76.745 \times 0.2134+79.992 \times \\
0.1739=76.399\end{array}$} \\
\hline $\begin{array}{l}\text { C busi- } \\
\text { ness's } \\
\text { total } \\
\text { score }\end{array}$ & \multicolumn{9}{|c|}{$\begin{array}{l}44.202 \times 0.2213+45.4585 \times 0.1350+48.973 \times 0.2563+63.1455 \times 0.2134+58.3125 \times \\
0.1739=52.086\end{array}$} \\
\hline
\end{tabular}

\section{Conclusions}

In the study, a quality credit evaluation system for the Internet company is proposed. Quality credit is defined as a function of three dimensions: willingness, ability, and environment. An AHP-based model is formulated to assess and combine the critical criteria in the quality credit evaluation of the company. From the survey results, B31Qualification rate of product supervise (0.1012), B21 Operating legitimacy (0.0838) and B15 Quality accident (0.0821) are the most important three items in this quality credit evaluation system, and these three items are "bottom line" for product quality or company quality. Consequently, the importance of the weight of these three items can explain the overall quality level of the Internet company is poor, and consumers have to pay more attention to the basic items of quality assurance. In contrast, items related to the consumer satisfaction: B12 Customer satisfaction (0.0147) and the record of consumer complaints (0.0201) are two items with the lowest weight among the sub-criteria and these two items means the "top line" for product quality or company quality. The weight of consumer satisfaction indicates that concerns of consumers are still more on the bottom line items. Therefore, to enhance the trust and satisfaction of consumers, the primary action is that the government and industry regulators need to strengthen their supervision further. They should increase the penalties level for dishonest behaviours, increase the cost of defaults, and create an excellent environment for honesty. Based on these actions and methods, the overall quality credit level of the Internet company will be improved. 
To demonstrate the concept of the proposed system, a few companies of the United States are evaluated using the quality credit evaluation and the data comes from Consumer Reports. The ranking of Quality Credit Scores is the same as Reader scores by analyzing relevant literature and collection data. There are two aspects of optimization: (1) the score gap is larger, which is more conducive to consumers' choice of the product or the company; (2) the contradiction between sub-items' scores and total score is identified (the ranking change between Costco and L. L. Bean), which further optimizes the ranking of company scores. Therefore, the applicability of Quality Credit evaluation index system is explained, but at the same time, only some items of the evaluation system are applied due to data limitation. This system involves difficulties and challenges because data about the criteria are not easily available occasionally. Once properly used and implemented in an Internet enterprise, the AHP should improve the enterprise's quality credit evaluation decision-making process.

There are two main limitations of this study. Firstly, company's data from Consumer Reports only cover some parts of the items in the evaluation system and based on this making only be conducted for some items. Secondly, more and more Internet companies are appearing because of the quick development of the Internet, which have different characteristics, especially in various industries. However, the Internet company is conducted an overall analysis without considering the differences between different categories of Internet companies. Future researches can focus on different industries that operate on the Internet, which lacks a quality credit evaluation system, such as Internet-finance, Internet-service, and so on. These future studies may explore different quality credit evaluation systems for these industries.

\section{Acknowledgements}

This work was supported by the National Natural Science Foundation of China under Grant [No. 71403253]; Zhejiang Provincial Natural Science Foundation of China under Grant [Nos LQ13G020006 and LY18G030020]; Zhejiang Provincial Science Technology Project of China under Grant [No. 2019C25011]; The National Key R\&D Program of China under Grant [No. 2018YFF0213105].

\section{References}

Aczel, J., \& Saaty, T. L. (1983). Procedures for synthesizing ratio judgements. Journal of Mathematical Psychology, 27, 93-102. https://doi.org/10.1016/0022-2496(83)90028-7

Agus, A., \& Sagir, R. M. (2001). The structural relationships between total quality management, competitive advantage and bottom line financial performance: An empirical study of Malaysian manufacturing companies. Total Quality Management, 12(7-8), 1018-1024.

https://doi.org/10.1080/09544120100000029

Alonso, J., \& Lamata, T. (2006). Consistency in the analytic hierarchy process: A new approach. International Journal of Uncertainty, Fuzziness and Knowledge-Based Systems, 14(4), 445-459. https://doi.org/10.1142/S0218488506004114

Amar, K., \& Zain, M. Z. (2002). Barriers to implementing TQM in Indonesian manufacturing organizations. The TQM Magazine, 14(6), 367-372. https://doi.org/10.1108/09544780210447474 
Barrett, J. (2009). Corporate social responsibility and quality management revisited. The Journal for Quality and Participation, 31(4), 24-30.

Belton, V., \& Gear, T. (1983). On a short-coming of Saaty's method of analytic hierarchies. Omega, 11(3), 228-230. https://doi.org/10.1016/0305-0483(83)90047-6

Chaker, M. N., \& Jabnoun, N. (2010). Barriers to service quality in Islamic banks in Qatar. International Journal of Commerce and Management, 20(4), 296-307. https://doi.org/10.1108/10569211011094622

Cheng, E. W. L., \& Li, H. (2001). Analytic hierarchy process: an approach to determine measures for business performance. Measuring Business Excellence, 5, 30-36. https://doi.org/10.1108/EUM0000000005864

China Internet Network Information Center. (2019). http://www.cac.gov.cn/wxb_pdf/0228043.pdf

China National Institute of Standardization. (2009). General rules of grading enterprise quality credit (GB/T23791-2009). https://www.chinesestandard.net/PDF/English.aspx/GBT23791-2009

China’s Consumer Net. (2018). http://www.100ec.cn/detail--6501474.html

China's e-commerce complaints and rights protection public services platform. (2018). http://www.100ec.cn/zt/2018yhts/

Ferreira, F., \& Santos, S. (2016). Comparing trade-off adjustments in credit risk analysis of mortgage loans using AHP, Delphi and MACBETH. International Journal of Strategic Property Management, 20(1), 44-63. https://doi.org/10.3846/1648715X.2015.1105321

Ferreira, F., Santos, S., \& Dias, V. (2014). An AHP-based approach to credit risk evaluation of mortgage loans. International Journal of Strategic Property Management, 18(1), 38-55. https://doi.org/10.3846/1648715X.2013.863812

General Administration of Quality Supervision, Inspection and Quarantine of the People's Republic of China. (2006). Opinions on strengthening the supervision of corporate credit quality.

Guo, G. (2017). Strengthen the standardization system construction to improve operational efficiency and respond to market competition. China Survey and Design, 10, 74-77.

Ye, R., Tang, W., \& Zhou, L. (2010). The connotation of quality credit economics based on quality contract. Productivity Research, 12.

Yu, J., Yao, J., \& Chen, Y. (2019). Credit scoring with AHP and fuzzy comprehensive evaluation based on behavioural data from weibo platform. Tehnicki vjesnik-technical gazette, 26(2), 462-470. https://doi.org/10.17559/TV-20181217180231

Yurdakul, M., \& Iç, Y. T. (2004). AHP approach in the credit evaluation of the manufacturing firms in Turkey. International Journal of Production Economics, 88(3), 269-289. https://doi.org/10.1016/S0925-5273(03)00189-0

Jabnoun, N., \& Sedrani, K. (2005). TQM, Culture, and Performance in UAE Manufacturing Firms. Quality Management Journal, 12(4), 10-16. https://doi.org/10.1080/10686967.2005.11919267

Jiang, J. (2004). Analysis of enterprise quality credit. Aeronautic Standardization \& Quality, 11, 8-11.

Li, D. (2017). Research on the impact of credit value on enterprise development. In 9th International Economics, Management and Education Technology Conference (pp. 300-304).

Liu, Y., \& Yang, M. (2000). Let more national brand rise in the competition. Chinese \& Foreign Corporation Culture, 23, 49-50.

Liu, L., Qian, H., Gao, Y.,, \& Wang, D.. (2011). Hybrid strategy for product quality credit evaluation based on statistics and artificial neural network. Advanced Materials Research, 361-363, 1499-1505. https://doi.org/10.4028/www.scientific.net/AMR.361-363.1499

Luo, X., \& Li, T. (2017). Study on the application of analytic hierarchy process in the evaluation standard of enterprise quality credit rating. China Quality and Standards Review, 6, 66-74. 
Moreno-Jimenez, J. M., \& Vargas, L. G. (1993). A probabilistic study of preference structures in the analytic hierarchy process with interval judgments. Mathematical and Computer Modelling, 17, 73-81. https://doi.org/10.1016/0895-7177(93)90176-Y

Saaty, T. L. (1977). A scaling method for priorities in hierarchical structures. Journal of Mathematical Psychology, 15, 234-281. https://doi.org/10.1016/0022-2496(77)90033-5

Saaty, T. L., \& Vargas, L. G. (2007). Dispersion of group judgments. Mathematical and Computer Modelling, 46, 918-925. https://doi.org/10.1016/j.mcm.2007.03.004

Saaty, T. L., \& Vargas, L. G. (2012). The possibility of group choice: pairwise comparions and merging functions. Social Choice Welfare, 38, 481-496. https://doi.org/10.1007/s00355-011-0541-6

Sheng, Y. (2008). On the construction of quality credit system in the whole process of supervision. China Quality and Technical Supervision, 6, 54-56.

Wang, P., \& Mo, M. (2019). A summary of research on enterprise quality credit evaluation system. Guangxi Quality Supervision, 2, 31-32.

Xian, K., \& Ye, R. (2008). Research of enterprise quality credit evaluation model and application based on product quality records. World Standardization \& Quality Management, 1, 45-48.

Xiong, W., Fan, L., \& Hu, Y. (2013). Research of enterprise quality credit evaluation index system: an empirical analysis based on 456 manufacturing industries in Zhejiang Province. East China Economic Management, 11, 1-5.

Xiong, X., \& Liu, Y. (2009). Research on China's enterprise quality credit evaluation system. Modern Economic Information, 17.

Zeliha, K. E., \& Girginer, N. (2015). Evaluation of banks' commercial credit applications using the analytic hierarchy process and Grey relational analysis: a comparison between public and private banks. South African Journal of Economic and Management Sciences, 18(3), 308-324. https://doi.org/10.4102/sajems.v18i3.744

Zhang, D., \& Gao, Q. (2010). Evaluation of enterprise quality credit rating: taking Qingdao Household appliance industry as an example. Journal of Systems Management, 19(1), 83-88.

Zhou, L., Ye, R., Xian, K., \& Wang, Y. (2012). Theory and practice of building a system of product quality and credibility. China Zhijian Publishing House, Beijing.

Zhou, X., \& Tu, Z. (2018). Research on the construction path of product quality credit evaluation system. Quality Exploration, 15(4), 58-64.

Zhu, X., Wang, F., Liang, C., Li, J., \& Sun, X. (2012). Quality credit evaluation based on topsis: evidence from air-conditioning market in China. Procedia Computer Science, 9, 1256-1262. https://doi.org/10.1016/j.procs.2012.04.137 


\section{APPENDIX}

Appendices should be used only when sophisticated technical details are crucial to be included in the paper. Prepared scorecards for measure under the quality credit evaluation system are given in Table 18.

Table 18. Scorecards for Sub-criteria items

\begin{tabular}{|c|c|c|c|c|c|c|c|c|}
\hline \multirow{2}{*}{ Criteria } & \multirow{2}{*}{ Weights } & \multirow{2}{*}{ Sub-criteria } & \multirow{2}{*}{ Weights } & 5 & 4 & 3 & 2 & 1 \\
\hline & & & & $(80-100)$ & $(70-80)$ & $(60-70)$ & $(40-60)$ & $(0-40)$ \\
\hline \multirow{6}{*}{$\begin{array}{l}\text { Credit } \\
\text { records }\end{array}$} & \multirow{6}{*}{0.2213} & $\begin{array}{l}\text { The record of } \\
\text { consumer complaints }\end{array}$ & 0.0908 & \multirow{2}{*}{$\begin{array}{l}\text { Less than } \\
\text { average } \\
(>10 \%)\end{array}$} & \multirow{2}{*}{$\begin{array}{l}\text { Less than } \\
\text { average } \\
(5-10 \%)\end{array}$} & \multirow{2}{*}{$\begin{array}{l}\text { Less than } \\
\text { average } \\
(0-5 \%)\end{array}$} & \multirow{2}{*}{$\begin{array}{l}\text { The ave- } \\
\text { rage of } \\
\text { industry }\end{array}$} & \multirow{2}{*}{$\begin{array}{l}\text { More } \\
\text { than } \\
\text { average }\end{array}$} \\
\hline & & Customer satisfaction & 0.0662 & & & & & \\
\hline & & $\begin{array}{l}\text { The record of quality } \\
\text { illegal }\end{array}$ & 0.2518 & \multicolumn{5}{|c|}{$\begin{array}{l}\text { Whether enterprise has records of breach of contract, } \\
\text { fraud and other quality illegal behavior }\end{array}$} \\
\hline & & $\begin{array}{l}\text { False propaganda of } \\
\text { product quality }\end{array}$ & 0.1168 & \multicolumn{5}{|c|}{$\begin{array}{l}\text { Whether enterprise has false product propaganda, } \\
\text { whether false propaganda causes significant damage } \\
\text { and loss }\end{array}$} \\
\hline & & Quality accident & 0.3710 & \multicolumn{5}{|c|}{$\begin{array}{l}\text { Whether enterprise has quality accident, whether } \\
\text { quality accident causes significant damage and loss }\end{array}$} \\
\hline & & $\begin{array}{l}\text { Others disciplinary } \\
\text { record }\end{array}$ & 0.1033 & \multicolumn{5}{|c|}{$\begin{array}{l}\text { Whether enterprise has records of bad bank record, tax } \\
\text { evasion records and other bad behavior }\end{array}$} \\
\hline \multirow{3}{*}{$\begin{array}{l}\text { Com- } \\
\text { pany } \\
\text { status }\end{array}$} & \multirow{3}{*}{0.1350} & Operating legitimacy & 0.6211 & \multicolumn{5}{|c|}{$\begin{array}{l}\text { Whether enterprise has illegal operation, whether } \\
\text { illegal operation causes significant damage and loss to } \\
\text { customer or society }\end{array}$} \\
\hline & & $\begin{array}{l}\text { The nature of the } \\
\text { enterprise and the } \\
\text { status of the industry }\end{array}$ & 0.1505 & \multicolumn{5}{|c|}{$\begin{array}{l}\text { For example: } 5 \text { means: A publicly owned corporation, } \\
\text { and its shares are valued by investors. An important } \\
\text { portion of the shares is held by bigger funds. } 1 \text { means: } \\
\text { This limited corporation is having management } \\
\text { problems. Owners have difficulty in establishing a } \\
\text { professional management team }\end{array}$} \\
\hline & & Quality honorary title & 0.2284 & $\begin{array}{l}\text { National } \\
\text { level }\end{array}$ & $\begin{array}{l}\text { Provincial } \\
\text { level }\end{array}$ & $\begin{array}{l}\text { Muni- } \\
\text { cipal } \\
\text { level }\end{array}$ & $\begin{array}{l}\text { District } \\
\text { level }\end{array}$ & No \\
\hline \multirow{5}{*}{$\begin{array}{l}\text { Quality } \\
\text { of } \\
\text { product }\end{array}$} & \multirow{5}{*}{0.2563} & $\begin{array}{l}\text { Qualification rate of } \\
\text { product supervise }\end{array}$ & 0.3948 & $\begin{array}{l}\text { More } \\
\text { than } \\
\text { average } \\
(>10 \%)\end{array}$ & $\begin{array}{l}\text { More } \\
\text { than } \\
\text { average } \\
(5-10 \%)\end{array}$ & $\begin{array}{l}\text { More } \\
\text { than } \\
\text { average } \\
(0-5 \%)\end{array}$ & $\begin{array}{l}\text { The } \\
\text { average } \\
\text { of } \\
\text { industry }\end{array}$ & $\begin{array}{l}\text { Less than } \\
\text { average }\end{array}$ \\
\hline & & $\begin{array}{l}\text { The level of product } \\
\text { technology (R\&D) }\end{array}$ & 0.1871 & \multicolumn{5}{|c|}{$\begin{array}{l}\text { Sales }>2 \text { billions, then R\&D }>3 \% \\
5 \text { millions }<\text { Sales }<2 \text { billions, then R\&D }>4 \% \\
\text { Sales }<5 \text { millions, } R \& D>5 \%\end{array}$} \\
\hline & & Standard using rate & 0.1742 & \multicolumn{5}{|c|}{$\begin{array}{l}\text { Whether enterprise has used product standard, how } \\
\text { many standards enterprises has used, including } \\
\text { International standards, GB and so on }\end{array}$} \\
\hline & & Brand Building & 0.1082 & \multicolumn{5}{|c|}{ The proportion of independent brand products } \\
\hline & & Quality certification & 0.1357 & \multicolumn{5}{|c|}{$\begin{array}{l}\text { How many years the enterprise has attained ISO9000 } \\
\text { system certification }\end{array}$} \\
\hline
\end{tabular}




\begin{tabular}{|c|c|c|c|c|c|c|c|c|}
\hline \multirow{2}{*}{ Criteria } & \multirow{2}{*}{ Weights } & \multirow{2}{*}{ Sub-criteria } & \multirow{2}{*}{ Weights } & 5 & 4 & 3 & 2 & 1 \\
\hline & & & & $(80-100)$ & $(70-80)$ & $(60-70)$ & $(40-60)$ & $(0-40)$ \\
\hline \multirow{8}{*}{$\begin{array}{l}\text { Quality } \\
\text { of } \\
\text { service }\end{array}$} & \multirow{8}{*}{0.2134} & & & \multicolumn{5}{|c|}{ Strongly agree ----------------------Strongly disagree } \\
\hline & & Service staff attitude & 0.1172 & \multicolumn{5}{|c|}{$\begin{array}{l}\text { Employees behave in a proper manner and treat } \\
\text { customers genuinely }\end{array}$} \\
\hline & & Staff professional & 0.1238 & \multicolumn{5}{|c|}{ Employees are of required knowledge and skills } \\
\hline & & Response time & 0.1442 & \multicolumn{5}{|c|}{ Employees give prompt service to customers } \\
\hline & & Complaint solving & 0.1499 & \multicolumn{5}{|c|}{$\begin{array}{l}\text { Employees can promptly response and effectively deal } \\
\text { with customer complaints }\end{array}$} \\
\hline & & Logistics and delivery & 0.0972 & \multicolumn{5}{|c|}{$\begin{array}{l}\text { The logistics service charge is fair and reasonable, and } \\
\text { the delivery accuracy is well done. }\end{array}$} \\
\hline & & Pay security & 0.2333 & \multicolumn{5}{|c|}{ The payment is convenient and safe } \\
\hline & & After-sales service & 0.1343 & \multicolumn{5}{|c|}{$\begin{array}{l}\text { The enterprise can keep necessarily contact with } \\
\text { customers and provide needed services after sales }\end{array}$} \\
\hline \multirow{4}{*}{$\begin{array}{l}\text { Industry } \\
\text { environ- } \\
\text { ment }\end{array}$} & \multirow{4}{*}{0.1739} & $\begin{array}{l}\text { Industry supervision } \\
\text { and punishment }\end{array}$ & 0.3363 & \multicolumn{5}{|c|}{$\begin{array}{l}\text { The industry association or union has prefect } \\
\text { supervision system and harsh punishment mechanism }\end{array}$} \\
\hline & & $\begin{array}{l}\text { Industry standard } \\
\text { system }\end{array}$ & 0.1814 & \multicolumn{5}{|c|}{ The industry has prefect standard system } \\
\hline & & Legal completeness & 0.3600 & \multicolumn{5}{|c|}{ Strongly completeness ---------Strongly incompleteness } \\
\hline & & Industry trends & 0.1222 & $\begin{array}{l}\text { Much } \\
\text { faster } \\
\text { than } \\
\text { GDP }\end{array}$ & $\begin{array}{l}\text { Faster } \\
\text { than } \\
\text { GDP }\end{array}$ & $\begin{array}{l}\text { Equal to } \\
\text { GDP }\end{array}$ & $\begin{array}{l}\text { Slower } \\
\text { than } \\
\text { GDP }\end{array}$ & $\begin{array}{l}\text { Negative } \\
\text { growth }\end{array}$ \\
\hline
\end{tabular}

